Review article

\title{
A comprehensive review of various categories of face masks resistant to Covid-19
}

\author{
Sonali Das ${ }^{\mathrm{a}, 1}$, Sagarika Sarkar ${ }^{\mathrm{b}, 1}$, Anusree Das $^{\mathrm{a}, 1}$, Shreyosree Das ${ }^{\mathrm{a}, 1}$, Pallab Chakraborty ${ }^{\mathrm{c}, 1}$, \\ Joy Sarkar ${ }^{\mathrm{a}, *}$ \\ ${ }^{a}$ Department of Botany, Dinabandhu Andrews College, 54, Raja S.C. Mallick Road, Garia, Kolkata, West Bengal, 700084, India \\ ${ }^{\mathrm{b}}$ Department of Botany, Sarojini Naidu College for Women, 30, Jessore Rd, K.B.Sarani, Golpark, Kolkata, West Bengal, 700028, India \\ ${ }^{\mathrm{c}}$ Department of Botany, Acharya Prafulla Chandra College, New Barrakpur, Kolkata, West Bengal, 700131, India
}

\section{A R T I C L E I N F O}

\section{Keywords:}

COVID-19

WHO

Mask

Pandemic

\begin{abstract}
A B S T R A C T
The science about the usage of face masks by the common public to avert COVID-19 transmission is proceeding swiftly. A primary route of transmission of COVID-19 is probably through small respiratory droplets, and it is transmissible from asymptomatic and pre-symptomatic individuals. According to the World Health Organization, wearing a mask in public can help reduce the transmission of the COVID-19 virus. Different categories and types of masks and their usage are reviewed in this work. In a nutshell, this review work elucidates the aspects of utilizing the various face masks along with all possibilities to fight against the ongoing pandemic of COVID-19.
\end{abstract}

\section{Introduction}

World Health Organization (WHO), announced on January 30, 2020, a Public Health Emergency of International Concern (PHEIC) in response to the emersion of a novel coronavirus in Wuhan, China. Later, on March 11, 2020, WHO announced COVID-19 to be a pandemic, it is the 2 nd pandemic of the 21 st century after the pandemic of 2009 caused by influenza A H1N1. ${ }^{1,2}$

In the declaration by WHO on February 11, 2020, the Coronavirus disease (COVID-19) is caused by the virus named severe acute respiratory syndrome coronavirus 2 (SARS-CoV-2), which is genetically related to the coronavirus responsible for the SARS outbreak of $2003 .^{3}$

As of August 29, 2020, more than 24.7 million cases have been reported across 188 countries and territories, causing more than 837,000 deaths with a recovering of 16.2 million people. In this case, proactive infection monitoring criteria have been executed in hospital set-ups. ${ }^{4,5}$

To control the further outbreak of pandemic disease COVID-19 among people, WHO provided some guidelines and instructions to the general public to follow such as the continuous practice of hand hygiene, maintaining social distancing, wearing a mask in public, avoiding social gatherings and practising self-isolation and home quarantine. In addition, with the guidelines of WHO, the authorities also implemented some rules such as quarantine and testing of all travellers, closing and regulating the city and country borders, along with massive testing for case detection by RT-PCR (reverse-transcription polymerase chain reaction) technique. Later, stay at home order, lockdowns, home isolation, cancellation of mass gatherings and prohibiting traveling were acquired to several degrees and at various time points in several countries to alleviate the threat of community transmission. It is unclear when the outbreak will end, and there are no known vaccines or antiviral therapies that are $100 \%$ effective against the coronavirus. ${ }^{3,5}$ Though there has been working on immunization and numerous vaccines have been created so far, none of them can guarantee $100 \%$ efficacy against SARS-CoV-2. ${ }^{6-8}$

To handle the ongoing COVID -19 pandemic situation, the US Centers for Disease Control and Prevention (CDC) had recommended the public to put on face masks. Many Asian countries, which have had greater experience with new coronavirus infections, use public masks significantly more frequently. Face Masks have been recommended as a primary potent tool to control the COVID-19 outbreak in China. ${ }^{9}$ However, the World Health Organization (WHO) advises that face masks should only be worn by individuals caring for patients with suspected COVID-19 or those who are actively sneezing or coughing. ${ }^{10}$

Many governments around the world have introduced policies that recommend the wearing of masks to slow down the expanse of COVID19. Mandatory use and enforcement vary globally. While several

\footnotetext{
* Corresponding author.

E-mail address: jsarkar80@gmail.com (J. Sarkar).

1 These authors have contributed equally to this work.
} 
countries have passed legislation requiring the use of masks, others, like China, India, Japan, South Korea, and Taiwan, have issued more precise guidelines. $^{11}$

With the exponential spread and emergence of COVID 19, the usage and utility of masks and respirators for the common people have been advised by the government. ${ }^{10}$ The US CDC has recommended that the usage of Medical masks, surgical masks, cloth masks, fabric masks, and extended use of respirators can be deliberated with proper caution. Medical masks i.e., N95 respirators and surgical masks are prioritized for healthcare professionals which appears to protect against the virus. ${ }^{12}$ Countries, like Italy and Mexico, provided single-use masks for the common public upon mandating their use. ${ }^{11}$ If medical masks, surgical masks or respirators are not available then the general public can use homemade cloth masks that provide lesser protection but still afford the efficacy. ${ }^{13}$ Japan offered cotton masks without imposing mandatory use, whereas the Czech Republic and the United Kingdom urged citizens to use reusable masks. ${ }^{11}$ There is not yet enough data to determine which combination of mask policies are most effective in slowing the expanse of infection. However, it is advised to wear reusable face coverings or masks for the general public as an alternative to the single use face mask or surgical face masks used in healthcare sector. The usage of reusable cloth mask are effective in combating virus transmission to a certain extent when combined with non-clinical interventions such as maintaining social distance and hand hygiene. ${ }^{11}$ In one of the surveys, it is reported that 28,000 people aged between 16 and 74 years in 15 countries wore face masks because of the coronavirus outbreak. About more than $70 \%$ of people in India, China, Italy, Japan and Vietnam wore reusable face masks to protect themselves from coronavirus outbreaks. In the USA and other countries, the percentage is $50 \%$ and above . 9,11 The sensations during the previous five months show that mask usage was usually high ( $>75 \%)$ in certain locations, such as Asia and South and Central America, whereas it was always low (25 \%) in Northern Europe. In some nations, an improvement over time has been observed, which might help in evaluating the surging cases of covid-19 or mask-related requirements and guidance. ${ }^{11}$

These and associated data can support inform public health communications campaigns and endeavors considering mask-wearing to help slow the expanse of COVID-19 and could be borrowed to help evaluate how policies associate to practice around the world.

In this paper, we seek to elucidate the different aspects of masks. Specifically, we explore the different varieties of masks, their material composition and effectiveness in protecting the wearer from an airborne virus along with the guidelines of usage of masks and caring method of masks in detail.

We tend to provide more information to the general public about the types of masks and what mask they should choose in case of no medical or surgical mask is available.

\subsection{Transmission characteristics of Covid-19}

Every day, new information concerning the COVID-19's transmission emerges. It is mainly a respiratory disease and the spread of infection with this virus can range from people with mild, non-respiratory symptoms to extreme acute respiratory ailment, along with organ dysfunction, sepsis and death, while some infected people have no symptoms at all. According to recent reports, the coronavirus is transmitted among people via contact routes and respiratory droplets. Transmission can also happen through fomites in the infected person's immediate environment. Therefore, transmission can occur by direct contact with an infected person, or indirectly by contact with surfaces or objects used on or by the infected person ${ }^{5,14}$ (Fig. 1).

The threshold for the droplet size is ranging from $5 \mu \mathrm{m}$ to $10 \mu \mathrm{m}$. Droplet transmission happens when a healthy individual comes in close contact within $1 \mathrm{~m}$ with an infected person and is exposed to infectious respiratory droplets, through coughing, sneezing or close personal contact by mouth or nose. ${ }^{15}$

Airborne transmission of the COVID-19 virus may be possible in particular conditions where procedures to generate aerosols are performed. The research community has been discussing, whether the coronavirus, might furthermore circulate by aerosols in the deficiency of aerosol-generating procedures (AGPs). This is a province of strong research. As, air testing in clinical atmospheres where AGPs were not conducted, found RNA virus in some observations but not in others. ${ }^{16}$ Nevertheless, the existence of viral RNA is never similar to replication and infection competent (viable) virus that could be transmissible and able to adequate inoculum to commence invasive infection. Few

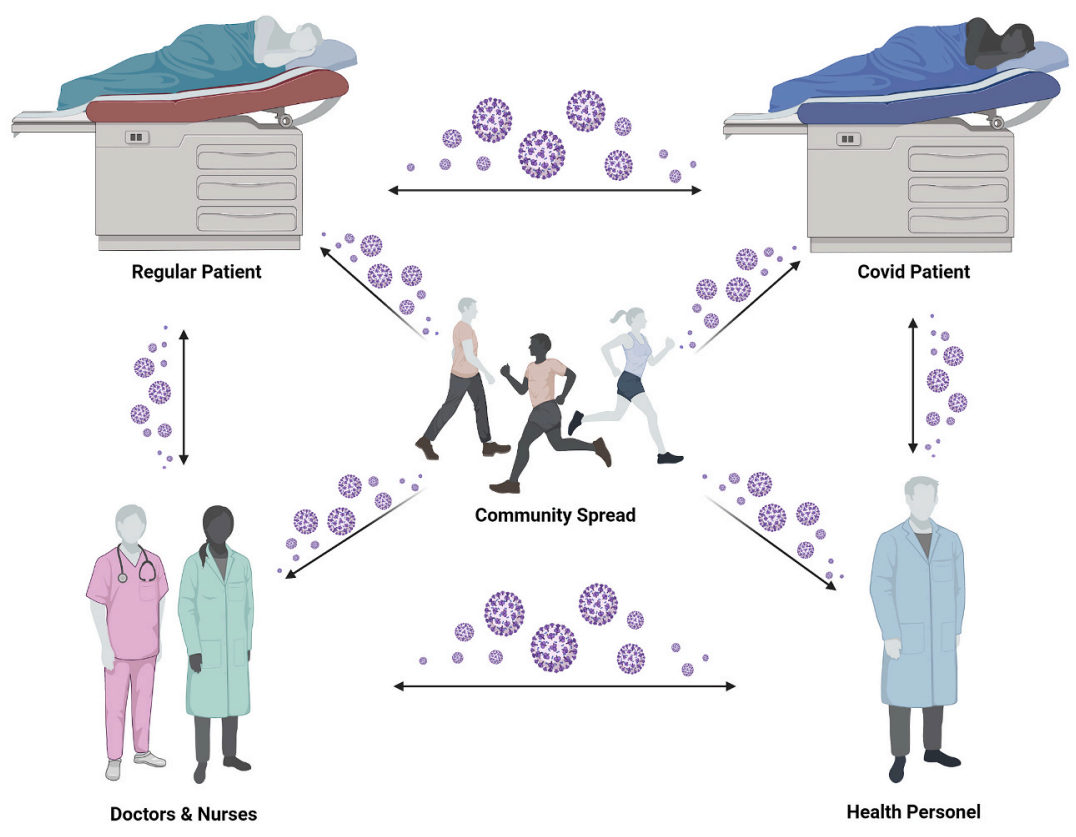

Local Transmission

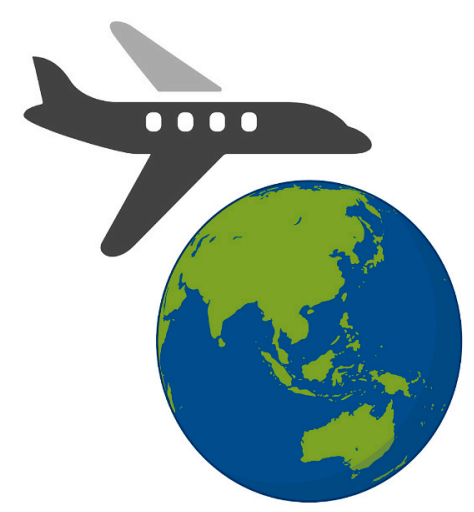

Global Transmission

Fig. 1. Diagram shows the different modes of COVID-19 disease transmission (Created with BioRender.com). 
experimental studies performed by aerobiology laboratories have found the viable virus and viral RNA, but these were experimentally induced AGP where aerosols were produced artificially using high-powered jet nebulizers and do not imitate normal human cough conditions. ${ }^{17}$

To address several of the acknowledged research gaps connected with AGPs and COVID-19 virus airborne propagation, high-quality research involving randomised trials in a variety of situations is required.

Recent information recommends that maximum expanse of COVID19 is happening from symptomatic people to others in near contact, when not wearing proper PPE. Amongst the infected persons with symptoms, viral RNA can be found in their specimens', weeks afterwards the commencement of sickness. However, for moderately infected individuals, the viable virus was not discovered after 8 days after the onset of symptoms, albeit this can change for very ill patients. ${ }^{18}$ In pre-symptomatic transmission, the infected person with no symptoms can transmit the virus to others. SARS-CoV-2 has an incubation period of 5- to 6-days, but it can last up to 14 days. ${ }^{19,20}$ Besides that, some data indicate that many people may test positive for coronavirus, using polymerase chain reaction (PCR) testing, 1-4 days before any symptoms develop. ${ }^{21}$

As per reports, some individuals infected with the SARS-CoV-2 virus does not ever develop any symptoms, though they can shed the virus that may, therefore, be transmitted to other people. According to a recent systematic analysis, $6 \%-42 \%$ of infected people are asymptomatic, and most of the studies in their evaluation have limitations due to inadequate symptom reporting. Comprehensive researches on the transmission from asymptomatic people are tough to perform, but the accessible proof from contact tracing documented by the Member States implies that asymptotically infected patients are much less likely to transmit the virus than those who develop symptoms. ${ }^{22}$

\subsection{Recommendations for wearing a face mask}

There have been reports on the usage of surgical face masks on patients with pulmonary tuberculosis, which significantly reduced transmission and offer an adjunct measure for reducing TB transmission from infectious patients to healthy persons. ${ }^{23,24}$ The surgical mask has further been revealed to disengage other human coronaviruses during coughing. In addition, a meta-analysis of randomised trials found that surgical masks and N95 respirators were equally effective in preventing influenza-like illness and laboratory-confirmed influenza among healthcare workers. ${ }^{25}$

The use of a mask to control a respiratory illness is a well-established method. A relevant investigation discovered that a cloth mask obstructed $96 \%$ of viral quantity on normal when used eight inches away to wheeze from a COVID-19-infected patient. ${ }^{26}$ It has been shown that every 10 -fold increase in viral amount results in an additional $26 \%$ increase in patient fatalities from acute infections caused by highly deadly viruses. ${ }^{27}$

The research focused on aerosol disclosure has found that all kinds of masks are at least somewhat beneficial at defending the wearer. Van der Sande et al. in 2008 reported that any mask can decrease aerosol exposure and are reasonably reliable over time. Researchers found that any type of mask use is likely to decrease viral exposure and infection hazard on a community grade, despite its improper fit. ${ }^{28}$

However, the examination of particle filtration is likely to misjudge the efficiency of masks, as the number of particles that are secreted as an aerosol is relatively small. ${ }^{29}$ Both homemade and medical masks are considerably useful in minimizing the number of microorganisms and can reduce the spread of infection, though the surgical mask was much better and be more useful in obstructing transmission in comparison to homemade masks. ${ }^{28}$ The scarcity of surgical masks and N95 respirators is a major issue. According to the current CDC advice, a healthy person should wear a cloth face mask in public. ${ }^{30}$

The importance of utilizing masks for health care persons has been detected in Chinese hospitals where, in each hospital, medical professionals wearing masks (particularly in quarantine areas) had no COVID-19 infections, instead of being around COVID-19 patients while other medical professionals had 10 or more infections in hospitals because of not wearing the mask. ${ }^{31}$

\subsection{Categories of face masks recommended by $W H O$}

During this COVID-19 epidemic, the usage of masks is suggested by Governments and WHO to control the further expanse of SARS-CoV-2. The usage of masks has followed various guidance from several community health organizations and governments. The WHO and other public health organizations approve that masks can inhibit the expanse of respiratory viral diseases, especially in COVID-19 case. $^{32}$

WHO recommends various kinds of masks for use in pandemic COVID-19 (Fig. 2). These types are mentioned as below:

\subsection{Categories of face masks include}

1. Cloth face masks

2. Medical or surgical masks

3. Respirators:

(i) Filtering facepiece respirator

- NIOSH respirator filter masks

(ii) Full-length face shield

(iii) Self-contained breathing apparatus (SCBA)

\section{Cloth face masks}

A cloth face mask is inexpensive and made of everyday cotton fabric that is worn over the mouth and nose. Many health authorities are instructed to use these cloth masks for protection if medical masks are unavailable in stocks. ${ }^{33}$

It is solely made of several varieties of cloth material. Studies demonstrate that the efficiency of these cloth masks, when compared to the N95 mask, is less effective against the SARS-CoV-2 but they can still provide the basic protection. It does provide the user protection against the air contaminants like pollens and dust particles. Therefore, it was limited approved in case of a pandemic.

Before the coronavirus outbreak, several Asian countries, including Vietnam and China, investigated the use of cloth masks in the community and healthcare. ${ }^{34,35}$ Cotton cloth masks were reported to be used by Health Care Workers (HCWs) in China during the outbreak of severe acute respiratory syndrome (SARS) in $2002 .{ }^{36}$

\subsection{Types of cloth masks}

Based on laboratory data and WHO's instruction, cloth masks are of three types: (a) Cloth mask 1, (b) Cloth mask 2, (c) Cloth mask 3.

Cloth mask 1 contains a latex exhalation valve, which worked better than the other two cloth masks that did not have an exhalation valve. The capability of filtration efficiencies of cloth masks 2 and 3 varied among the several PSL (polystyrene latex) sizes. Cloth masks 2 and 3 are more susceptible to penetration than cloth mask 1 . Cloth mask 1 , is an outstanding filtering mask with a conical or tetrahedral shape, that fits well with the general population. It also has 3 layers with a hydrophilic inner layer, filter in the middle layer and a hydrophobic outer layer whereas cloth masks 2 and 3 have simple rectangle long nooses and they do not possess three layers. Cloth mask 2 has two layers i.e. filter and hydrophobic outer layer while cloth mask 3 has only one thin layer (Fig. 3). This technique does not fit on the mannequin, allowing the leakage of a considerable percentage of components to infiltrate via the mask. When comparing filtering effectiveness and fit, cloth mask 1 outperformed the other two masks. However, the cloth mask 2 performed better when compared to cloth mask $3^{37}$

The most protective cloth face masks require at least three layers 
a.

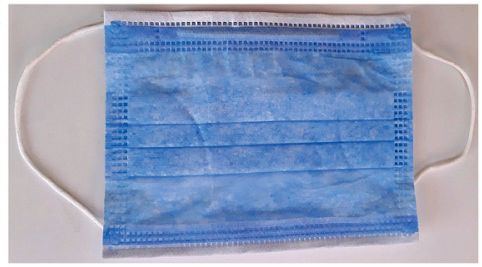

d.

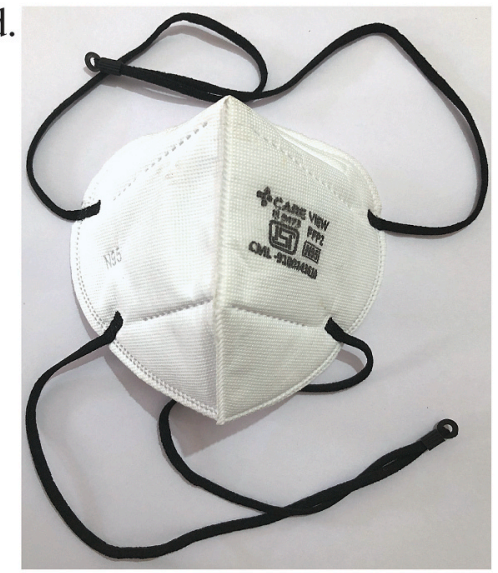

b.

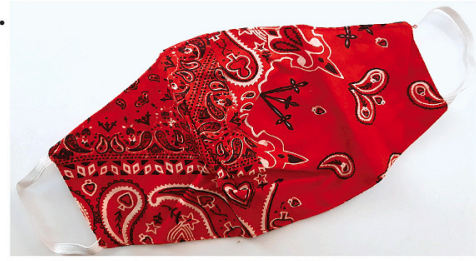

e.
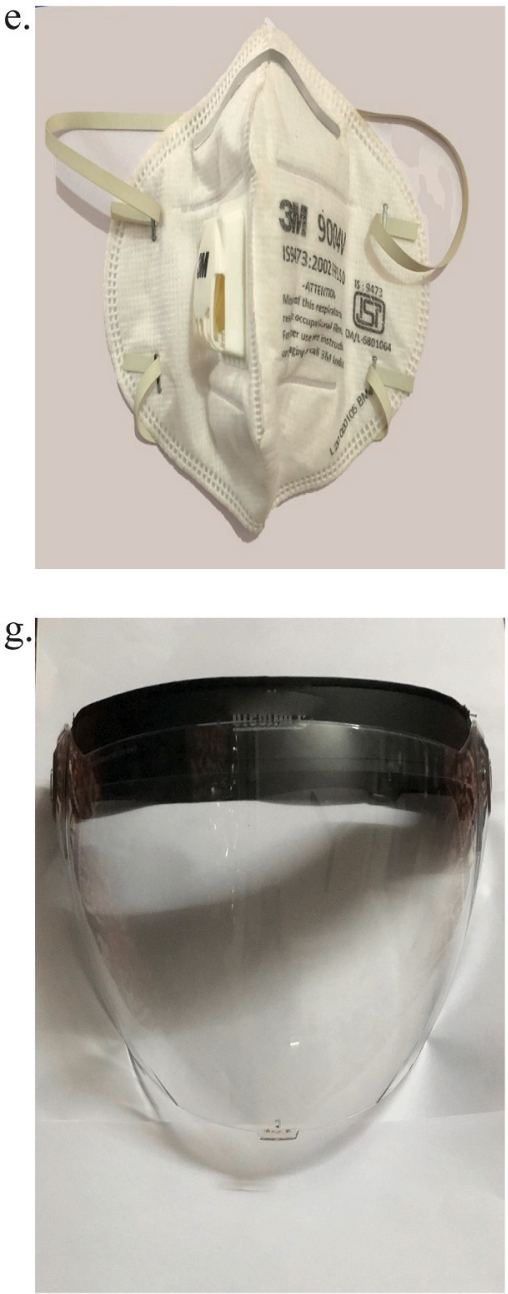

c.

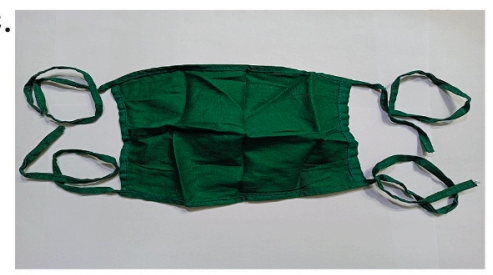

f.

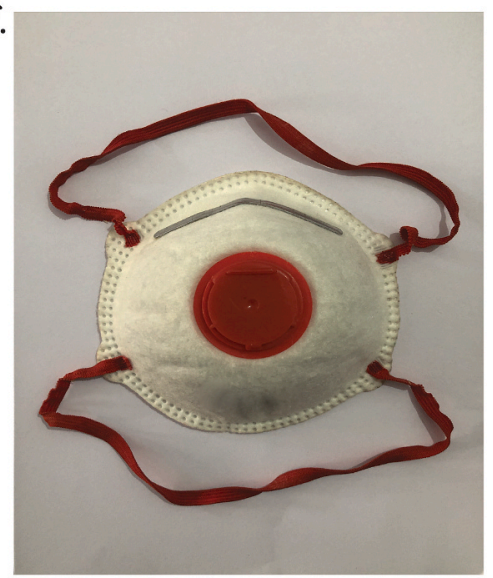

Fig. 2. Diagram shows the pictorial view of different types of masks: a. Surgical Mask b. Cloth Mask c. Cloth Mask with Head Loop d. Fold Model Type K95 Mask without Respirator with Head Loop e. Fold Model Type N95 Mask with Respirator and Head Loop f. Cup Model Type N95 Mask with Respirator and Head Loop g. Full-Length Face Shield.

with a hydrophilic inner layer (e.g. cotton) to consume moisture from the wearer's breathing and hydrophobic outer layers (e.g. polyester). ${ }^{37}$

Another study demonstrated that homemade masks made of tea cloth delivered safety during short- and long-term activities. ${ }^{28}$ Ma et al. demonstrated that while N95 respirators obstructed $99.98 \%$ of avian influenza virus, cloth homemade masks and surgical masks were comparative $95.15 \%$ and $97.14 \%$, respectively. These homemade masks were created from polyester and kitchen towels and were used in the experiment. ${ }^{34,38}$

\section{Medical or surgical mask}

During this moment of global health emergency caused by the COVID-19, WHO recommends medical or surgical masks for nurses, doctors, patients, and all hospital personnel, as well as all healthcare units, to protect themselves from COVID-19 exposure. A fluid-resistant (Type-IIR) medical face cover is utilized to keep safe against droplets.
If worn by the sufferer, it will underestimate the disbandment of enormous respiratory droplets that will defend workers against both droplets and influenced by the transmission of viruses. If worn by healthcare workers it will protect against droplet communication, when within 1-2 $\mathrm{m}$ of the victim. Danger removal by at least $80 \%$ is reckoned. ${ }^{39}$ Surgical masks contain three layers: an internal tender absorbent sheet, a central polypropylene obstacle, and an exterior hydrophobic surface. This face mask delivers protection from droplets in a clinical setting. The design of the surgical masks relies on the mode; usually, the masks are three-ply (three layers) and 4 ply (four layers). This three-ply fabric is composed of a meltblown polymer, most generally polypropylene, placed between the non-woven fabric. It has 3 layers, the external layer repels water droplets, the middle layer serves as a filter and the interior layer absorbs moisture (Fig. 4a \& 4b). Numerous analyses are carried out to disclose the removal of viral detection, which in turn was found to be 25 -fold for coarse aerosols, 2.5 fold for neat particles. Surgical face masks deliver the fundamental option in a pandemic. It had the 
a.

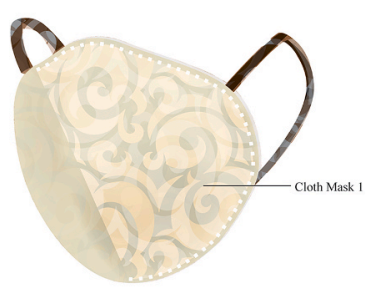

b.

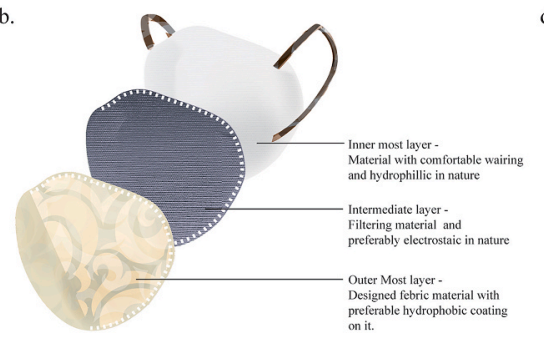

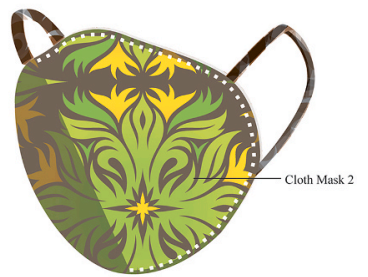

d.

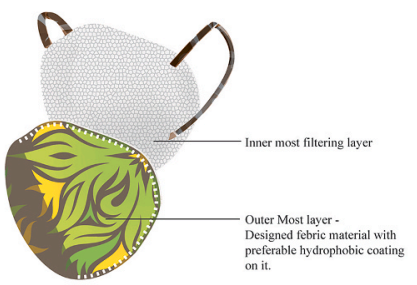

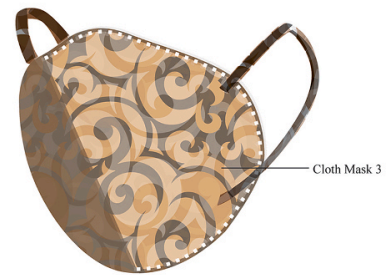

f.

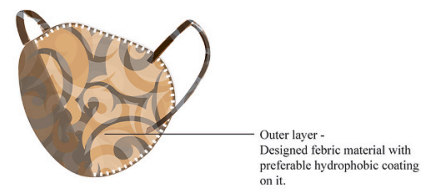

Fig. 3. Diagram shows the different types of cloth masks and their layering pattern: a. Cloth Mask $1 \mathbf{b}$. Different layering pattern of Cloth Mask 1 c. Cloth Mask 2 d. Different layering pattern of Cloth Mask 2 e. Cloth Mask 3 f. Different layering pattern of Cloth Mask 3.

a.

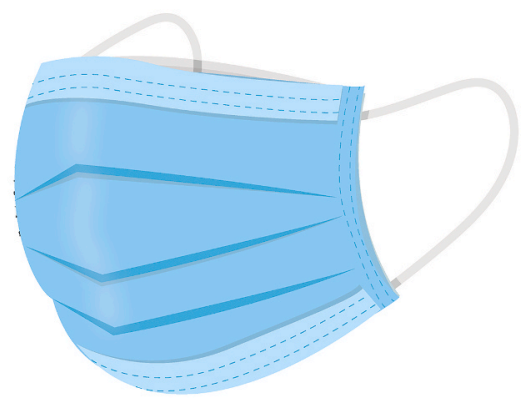

b.

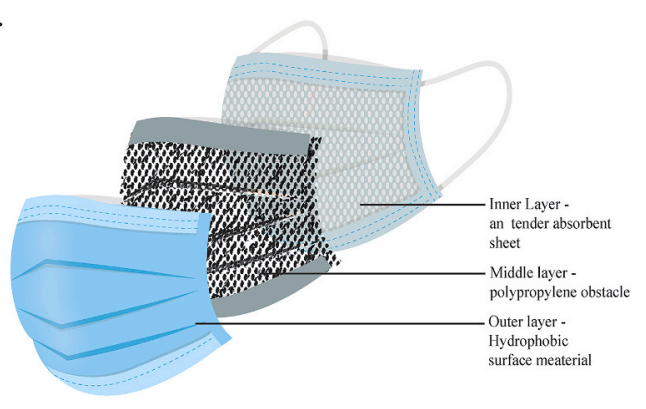

c.

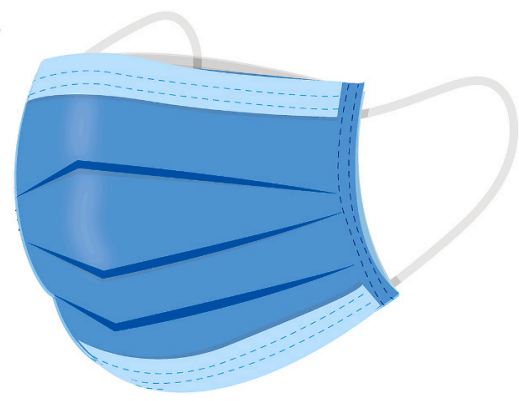

d.

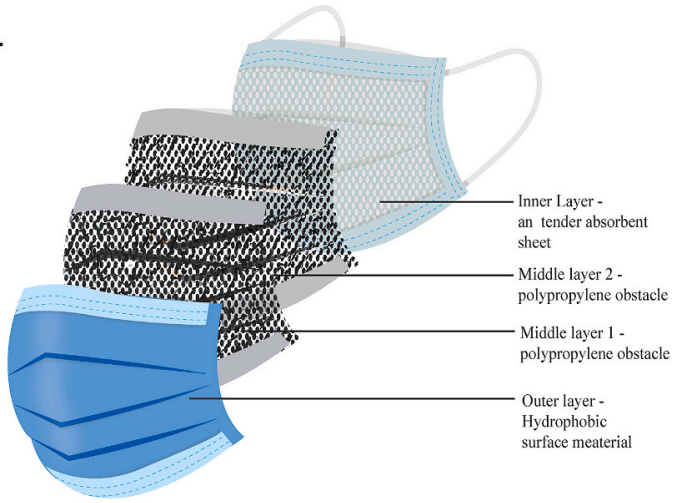

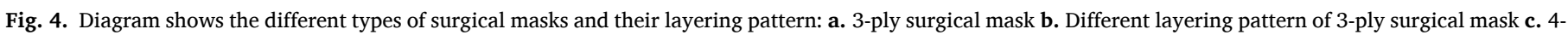
ply surgical mask d. Different layering pattern of 4-ply surgical mask.

drawback of not constraining the release of minor droplets. ${ }^{40}$

The 4 ply surgical mask is like a 3 ply face mask along with an added additional layer with an activated carbon filter or one more filtering layer (Fig. 4c \& 4d). The first layer is composed of polypropylene spun bond non-woven, second is with an active carbon filter fiber or another filtering layer. The 3rd layer is with melt-blown nonwoven fabric and the final layer is with polypropylene spun bond non-woven. They also have flexible nose strips to give extreme protection and satisfaction to the user. It also protects against odors as well as organic vapors. ${ }^{40}$

\section{Respirators}

FFP $1 / 2 / 3$ or NIOSH respirators and other respirators are seal-tested respirators and they are capable to protect health care workers especially those who directly come in contact with the patients. This apparatus causes a blockage around the nose and mouth and has twisted fibres with filters. WHO instructed about respirators, described below:

(i) Filtering Face-piece Respirators:

The term filtering facepiece (FFP) is utilized in source to highperformance screening masks. Filtration is executed by a variety of 
complex polypropylene microfibers and electrostatic rates. It is borrowed to filter out vapors, dust particles and infectious agents. It is primarily borrowed in the workplace having more pollutants. It has the benefit of cleansing air and cutting down the hazard of contamination of the wearer. Such mechanical filter respirators protect against the inhalation of particulates such as dust particles, droplets, and aerosols. ${ }^{40}$

Types of FFP Mask: There are three categories of protection. For FFP1, FFP2 and FFP3 these are 4-, 10- and 20-folds, respectively. FFP1 Filters at least $80 \%$ of airborne particles and FFP2 Filters at least $94 \%$ of airborne particles. ${ }^{40}$

The third category of FFP3 provides the longest aspect of precaution and is the only one recommended for UK healthcare locations, particularly in AGPs, such as intubation and non-invasive ventilation. They must comply with industry standards, including stringent industry tests with biological aerosols and a maximum leakage of $2 \%$. FFP3 respirators provide $99 \%$ protection against COVID-19 in screening elements ranging in size from 100 to $5000 \mathrm{~nm}$, including airborne tiny droplets. $^{41,42}$

NIOSH recognized different types of respirators are most popularly known as FFP respirators. As per the shape, it may be (i) cup model type or (ii) fold model type or (iii) linear model type. ${ }^{43}$ (Fig. 5).

\section{- NIOSH respirators filter masks:}

The NIOSH respirators screening masks are respiratory guarding equipment manufactured to conform a remarkably close facial clothing and very productive filtration of airborne components.

\subsection{Types of NIOSH respirator filter masks}

Based on filtering particles and efficiency of resistance to oil, NIOSH respirator filter are of three types: N, P, R.

Depend on particle filtering efficiency $N$-type respirators are of three categories- N95, N99, and N100. N95 respirators are generally used in healthcare vicinities and are a subset of N95 Filtering Facepiece Respirators (FFRs), often cited as N95s. ${ }^{37}$ The N95 designation means that under experimental circumstances which are approved by the United States CDC and National Institute for Occupational Safety and Health, the respirator hurdles at least $95 \%$ of strong and watery aerosol trial components. The most incredibly used is N95 which is called electrets filters, which has a filtration of $95 \%$ of aerosols N90/N95 face mask is one of nine NIOSH certified particle respirators. Obtaining an N95 mask as an example, "N" means not resistant to oil. "95" means that the particle concentration in the mask is $95 \%$ poorer than that outside the mask when disclosure to a specified number of special test particles. 95 $\%$ is not the normal filter rate, but the slightest value. N95 is not a certain product name. As long as the product meets the N95 criterion and upholds NIOSH review, it can be called "N95 mask". The degree of safety is N95, which means that under the test circumstances stipulated in NIOSH standard, the filtering efficacy of the filter substance of the mask for non-oily particles (such as acid mist, dust, paint mist, microorganism, etc.) attains $95 \%$. Nevertheless, various companies manufacture several $\mathrm{N} 95$ and its effectiveness relies on the size of penetrating particles. It has 4 layers-inner, filter, support and layer mask filter layer from outside to inside with a ventilator fan to permit reinforce breathing. N95 are of two categories- The standard N95 and surgical N95, which is more worthwhile. ${ }^{40}$ (Fig. 6).

Some other variants to the N95 mask are also available like N90, valved N90, valved N95, KN90 and KN95. In the case of the N90 mask, the number 90 signifies the effectiveness of the mask to filter out $2.5 \mathrm{p}$. m. dust particles. While KN90 respirators with valves are more favorable for industries of non-ferrous metal processing, food processing, metallurgy, construction works and all additional oil and non-oil particles pollutants such as dust particles, smoke fog. KN90 can apprehend more than $90 \%$ of particles. Although it is not as beneficial as KN90 in the case of particle conservation. KN90 is a promising choice to travel in a mist for a short time. ${ }^{11,40}$

There are a variety of respirators on the market that match the same design criteria as N95s, and they are approved as KN95s in China. These respirators are fundamentally the same. The KN95 filters out at least $95 \%$ of particles down to $0.3 \mu \mathrm{m}$ (Fig. 7). To be more useful, these respirators also must develop a seal around the nose and face when worn. Genuine N95s will have NIOSH written in block letters on the respirator, including testing and certification numbers, as well as the identification, N95. This can help recognize the fake masks on the markets. ${ }^{40}$

The usage of valves in face masks such as the valved N90 and N95 are stated as not prohibiting the virus from escaping out of the mask. The valve is almost a 'one-way valve' that only insures the person wearing it and does not purify the aerosols coming out. So, an asymptomatic person with coronavirus can scatter the infection to people when the valve discharges the unfiltered exhaled air in the sudden environment. Therefore, in a sealed area, people around the carrier have an increased threat of conceivable disclosure to the Covid-19. Asymptomatic transmission disseminates the infection to another person. On the other hand, a mask without a valve will not permit the virus to circulate. ${ }^{40}$

The $\mathrm{R}$ and $\mathrm{P}$ masks have friction to oils but the high-performance 100 refers to the lowest percentage of factors screened under trial conditions. Both R-type (Resistant to oil) and P-type (Strongly Resistant to oil/Oil Proof) of respirators differentiate into three types, viz., R95, R99, R100, and P95, P99, P100 respectively. Their filtering power is at least $99 \%$ and $99.7 \%$ respectively. ${ }^{42}$ The $\mathrm{P} 100$ respirator has a filtration of $99.7 \%$. Studies were performed to find and distinguish the efficiency of N95 and P100 before and post-exercise. The permeability values were more or less the same with both before exercise. But, the outline after exercise demonstrated change, having the benefit of using P100 masks. ${ }^{40}$

\section{(ii) Full-length face shield:}

It is made out of elastic headbands and a clear polycarbonate shield that runs across the face (Fig. 8). It prohibits the wearer from splashes of coughing and other liquid droplets. It had the advantage of being light and cost-effective. It is primarily used in a clinical area. ${ }^{40}$ a.

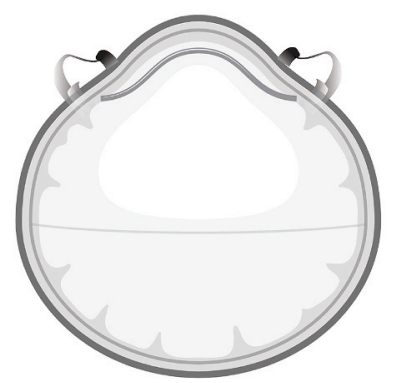

b.

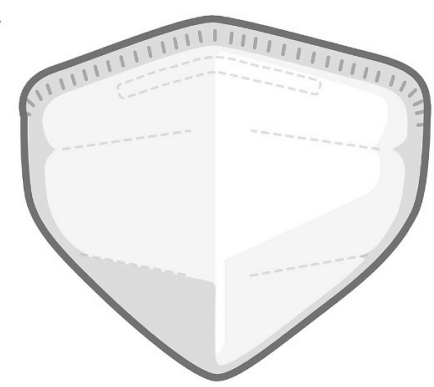

c.

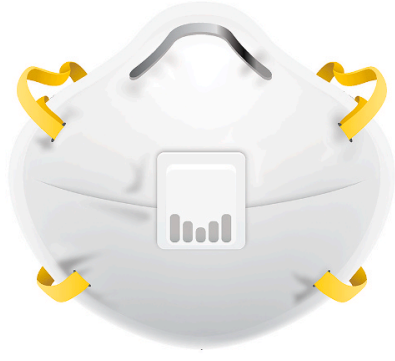

Fig. 5. Diagram shows the different shaped Filtering Face-Piece Respirators a. Cup Model Type b. Fold Model Type c. Liner Model Type (Created with BioRender.com). 
a.

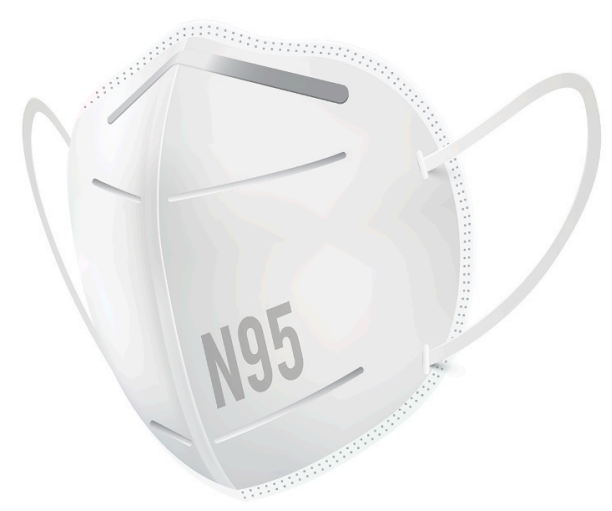

b.

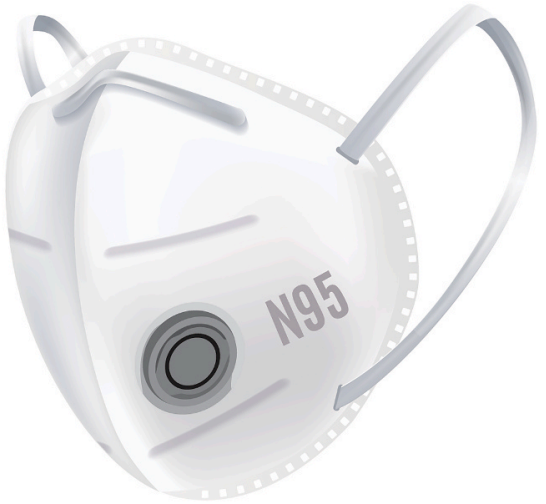

c.

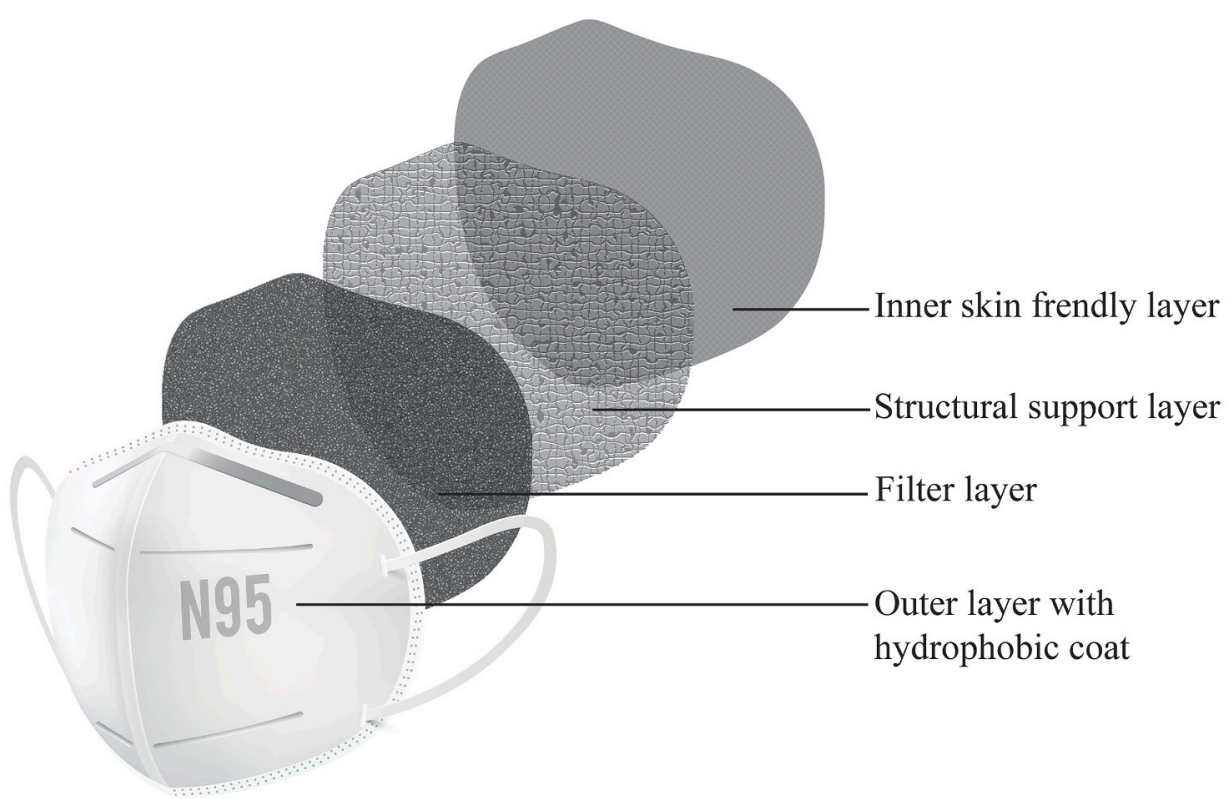

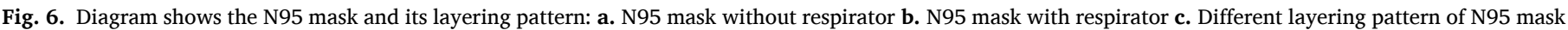
without respirator.

Full-length face shields come through different structures, but all deliver a plastic boundary for the face to protect against droplets and virus particles. The faceguard coverings will ensure that it reaches the chin and that there is no gap between the forehead and the face-shield guard. The laboratory study showed that the face guard was capable of inhibiting $96 \%$ viral particles when worn by health care personnel within 18 inches of cough. ${ }^{44}$ Yet social distancing, wearing masks must be important for avoiding viral respiratory diseases. ${ }^{22,45}$

(iii) Self-contained breathing apparatus (SCBA)

It comprises a facepiece that is connected to an allowance of liquid air or liquid oxygen. A hose and a regulator are used to keep the SCBA in place (Fig. 9). It primarily gives protect against airborne pollutants, making it easy for those working in a smoky environment. It is employed as personal firefighting cautionary. It has the disadvantage of being hefty, which limits the user's mobility in the workplace. ${ }^{40}$

Table 1 shows the many types of masks, their materials, characteristics, and purposes, as well as their percentage of effectiveness in protecting against the Coronavirus.

\subsection{Mechanistic significance of wearing a mask}

Over the last several months, the use of facemasks has been identified as one of the most important and cost-effective mitigating strategies for delaying COVID-19 transmission. In addition to government and public health officials' advice and mandates for mask use, a growing number of scientific studies have demonstrated the effectiveness of masks and universal masking.

Face Masks and different PPE items serve as a physical obstacle to respiratory droplets. An in vitro model with basis and receiver figures was developed to test the impact of the mask on filtering away radiolabelled aerosol. Masking at the source mannequin was invariably more beneficial at reducing radio-labelled aerosols entering the receiver mannequin, whereas the only practical setup where the receiver mannequin could be equally adequately conserved was if the receiver mannequin wore an N95 mask enclosed with Vaseline. ${ }^{47}$ Hence, masks can work as a physical obstacle and seem to be more significant when worn by an infected person.

The use of a mask by the infected person helps in reducing virus transmission. The surgical mask was examined for its potentiality to hinder the discharge of numerous viruses by investigating the quantity 


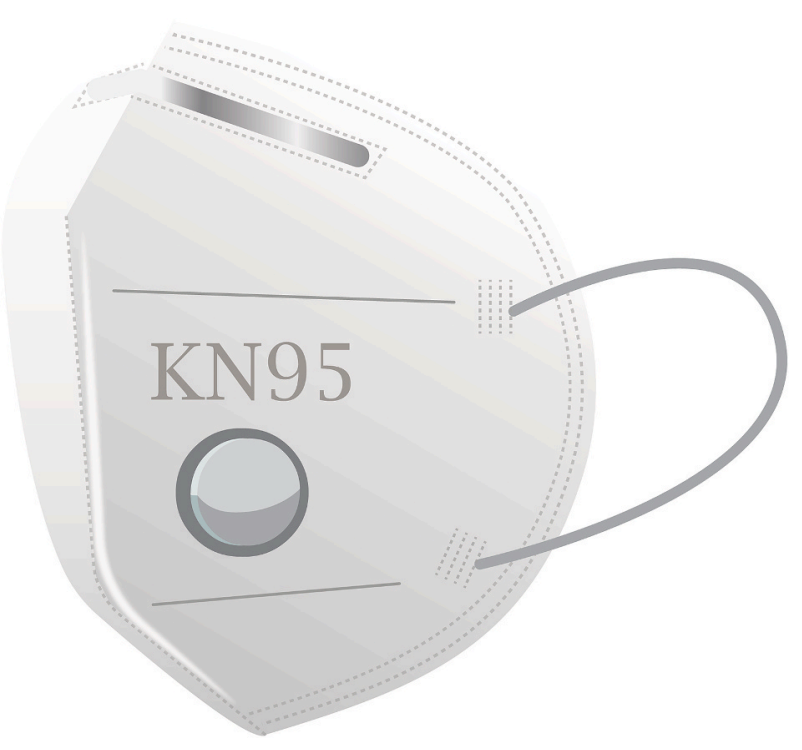

Fig. 7. Diagram shows the K95 mask.

of virus existing in the exhaled breath of the infected person. The researchers were able to obtain the particles distinguished by size ( $>$ or $<5$ $\mu \mathrm{m})$. With the mask on, a critical decline in coronaviruses in both smaller and bigger particles was investigated. The mask reduced the number of influenza viruses identified in bigger particles, but not in smaller particles. After wearing a mask, no coronavirus was found in any of the 11 patients, although influenza was found in the respiratory particles of one of them. ${ }^{48}$ This means that surgical face masks can reduce coronavirus and influenza transmission from an infected person. Participants were encouraged to cough for influenza trial, and no influenza could be detected by reverse transcriptase-polymerase chain reaction (RT-PCR) for 9 infected patients using both N95 and surgical masks. ${ }^{49}$ When the exhaled influenza virus was divided into amounts based on size, surgical masks were found to be highly effective at eliminating influenza from the large coarse portion $(\geq 5 \mu \mathrm{m}){ }^{50}$ Individuals who come into contact with an infected person can benefit from wearing face masks. During the SARS outbreak in Hong Kong, hospital faculties were asked about the preventative measures they took and this data was linked to whether or not they were infected. Wearing face masks was determined to be the most effective preventative measure in reducing the risk of infection, and those who wore surgical masks or N95 masks were not among the 11 infected employees. Nonetheless, two groups of people who wore paper masks became sick, implying that the types of masks were also important. ${ }^{51}$ A study distinguished the effectiveness of surgical and N95 masks against viral respiratory infections in healthcare employees. When healthcare workers used surgical masks or N95 masks, there was no significant difference in influenza infection outcomes, implying that both types of medical masks can protect equally. ${ }^{52}$ A meta-analysis was conducted on clinical surveys to investigate the protective impact of masks. Wearing a face mask protect persons against influenza-like illness, illustrating a risk ratio of 0.34 , with a $95 \%$ confidence duration between 0.14 and 0.82 . According to the study, there was a minimal difference in protection between N95 masks and surgical masks, with a hazard ratio of 0.84 and a $95 \%$ confidence duration of $0.36-1.99$, indicating no significant difference in risk. ${ }^{53}$ A study conducted by Eikenberry et al. suggested that the widespread use of masks by the general public can significantly reduce population transmission rates and death tolls. ${ }^{54}$ Hence, the study finds that the widespread use of face masks has the potential to significantly minimise community transmission and the threat of a COVID-19 pandemic. These data can be used to support and inform public health communications campaigns and undertakings involving the use of masks to help limit the spread of COVID-19, as well as to examine how policies and practices interact around the world.

\subsection{Caring methods of non-medical masks}

Masks should be worn by only one person and should not be shared. When masks become wet or dirty, they should be changed immediately; a patchy mask should not be worn for an extended amount of time. While removing the mask avoid touching the front side of the mask and do not touch any other part of the face after removing. Abandon the mask or keep it in a sealable pouch until it is cleaned and washed again. Afterwards, instantly practice hand hygiene. Non-medical masks should be washed frequently and handled carefully.

Do not use the mask, if the fabrics look notably worn out. The highest permissible washing temperature for clothing textiles used to make masks should be checked. Clean it in with soap or detergent in warm, hot water $\left(60{ }^{\circ} \mathrm{C}\right)$. Non-woven polypropylene (PP) spun-bond perhaps washed at high temperatures, up to $125{ }^{\circ} \mathrm{C} .{ }^{55}$ Naturalistic fibres may fend with high-temperature ironing and washes. Cleanup the mask exquisitely but avoid too much abrasion, extending or rubbing. The summation of cotton and non-woven PP spun bond can undergo high temperatures, masks formed of these compounds perhaps fumigated or steamed.

When warm water is not obtainable, wash the mask with detergent or soap at room temperature water, pursued by either (i) steaming mask for $1 \mathrm{~min}$ or, (ii) drench face cover in $0.1 \%$ chlorine for $1 \mathrm{~min}$. Rinse the mask properly with room temperature water to avoid any toxic chlorine accessorial.

Though the cloth masks may be created in huge quantities in a short amount of time, they can be reused after being decontaminated using a variety of methods, the most effective of which is washing in hot water with soap. Other methods or products, to get contaminant free cloth masks, are the use of bleach, isopropyl alcohol, or hydrogen peroxide;
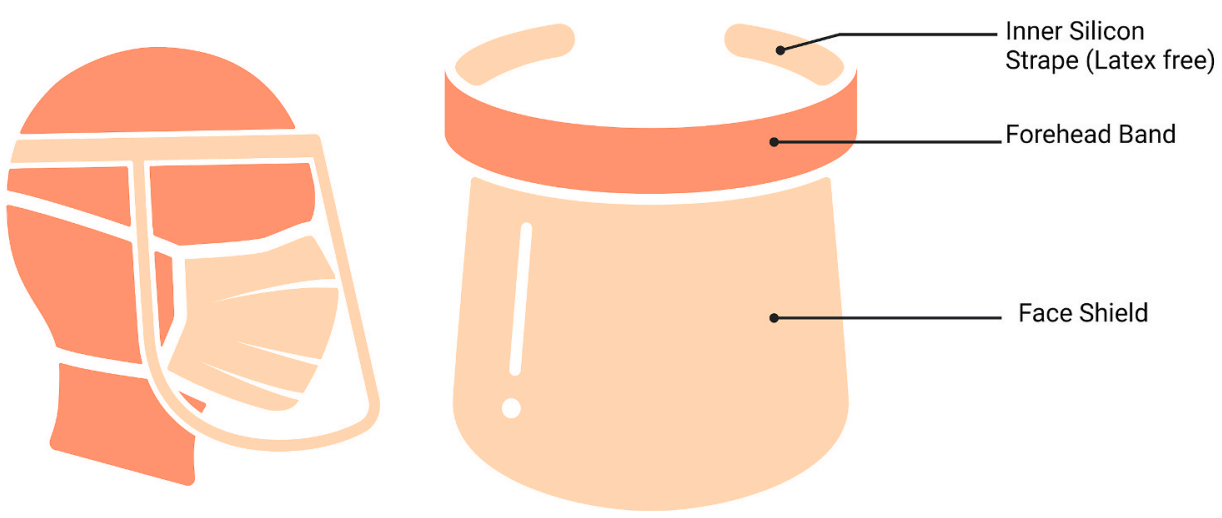

Fig. 8. Diagram shows the full-length face shield and its layering pattern (Created with BioRender.com). 


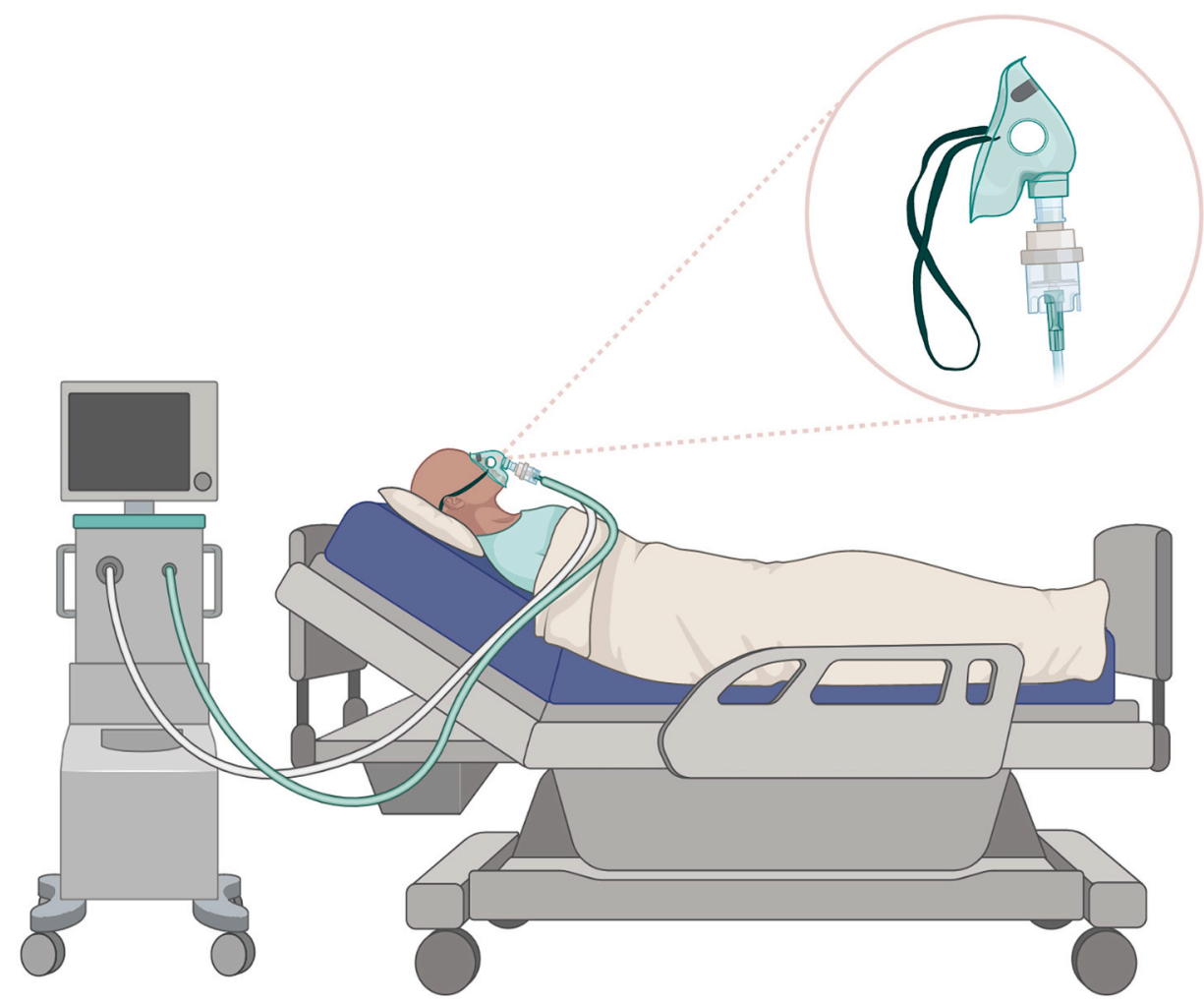

Fig. 9. Diagram shows the Self-Contained Breathing Apparatus (Created with BioRender.com).

Table 1

A detailed summary of the different types of masks and their effectiveness in protecting against the SARS-CoV-2 virus.

\begin{tabular}{|c|c|c|c|c|c|c|c|}
\hline $\begin{array}{l}\text { Type of } \\
\text { mask }\end{array}$ & Materials used & Description & $\begin{array}{l}\text { Efficiency in } \\
\text { percentage }\end{array}$ & Purpose & $\begin{array}{l}\text { Respiratory } \\
\text { filter }\end{array}$ & Reusable & Reference \\
\hline $\begin{array}{l}\text { Cloth Face } \\
\text { Mask }\end{array}$ & Common textiles, usually cotton & $\begin{array}{l}\text { The most protective cloth face masks } \\
\text { require at least three layers with a } \\
\text { hydrophilic inner layer (e.g. cotton) to } \\
\text { consume moisture from the wearer's } \\
\text { breathing and hydrophobic outer } \\
\text { layers (e.g. polyester). }\end{array}$ & $\begin{array}{l}\text { Zero } \% \text { efficient } \\
\text { at } 0.3 \mu \mathrm{m}\end{array}$ & $\begin{array}{l}\text { Dust Party leader, } \\
\text { virus and bacteria }\end{array}$ & No & Reusable & 40,46 \\
\hline $\begin{array}{l}\text { Surgical } \\
\text { Face } \\
\text { Mask }\end{array}$ & Non-woven fabric & $\begin{array}{l}\text { This mask has been certified by the } \\
\text { Food and drug administration. This } \\
\text { category of mask protects the mouth, } \\
\text { nose, eye, cheeks and forehead. It is } \\
\text { mostly referred to the Medical } \\
\text { professional dealing with operations } \\
\text { drive through COVID-19 patients. }\end{array}$ & $\begin{array}{l}60 \%-80 \% \\
\text { filtration of } \\
\text { particles as } \\
\text { small as } 0.3 \mu \mathrm{m}\end{array}$ & $\begin{array}{l}\text { Virus, bacteria, } \\
\text { pollen and dust } \\
\text { particles }\end{array}$ & No & Disposable & 40,46 \\
\hline $\begin{array}{l}\text { N95 Face } \\
\text { Mask }\end{array}$ & $\begin{array}{l}\text { Fine mesh of synthetic polymer } \\
\text { fibres, specifically a non-woven } \\
\text { polypropylene fabric. }\end{array}$ & $\begin{array}{l}\text { This mask is mostly recommended by } \\
\text { health care workers and first medical } \\
\text { responders dealing with COVID-19 } \\
\text { patients. }\end{array}$ & $\begin{array}{l}95 \% \text { efficient of } \\
\text { particles sized } \\
0.1-0.3 \mu \mathrm{m}\end{array}$ & $\begin{array}{l}\text { Virus, bacteria, } \\
\text { pollens, liquid like } \\
\text { sprays against non- } \\
\text { oil particles }\end{array}$ & Yes & Reusable & $12,40,46$ \\
\hline $\begin{array}{l}\text { FFPR } \\
\text { (P100) } \\
\text { Face } \\
\text { Mask }\end{array}$ & $\begin{array}{l}\text { Fine mesh of synthetic polymer } \\
\text { fibres, specifically a non-woven } \\
\text { polypropylene fabric. }\end{array}$ & $\begin{array}{l}\text { Unlike the surgical mask, this type of } \\
\text { mask is mostly used to stop the spread } \\
\text { of airborne diseases and also is } \\
\text { dispensable. }\end{array}$ & $\begin{array}{l}99.97 \% \\
\text { efficient of } \\
\text { particles sized } \\
0.1-0.3 \mu \mathrm{m}\end{array}$ & $\begin{array}{l}\text { Virus, bacteria, dust } \\
\text { particles. }\end{array}$ & Yes & Reusable & $12,40,46$ \\
\hline $\begin{array}{l}\text { KN95 Face } \\
\text { Mask }\end{array}$ & $\begin{array}{l}\text { Non-woven fabric, often made } \\
\text { from polypropylene. }\end{array}$ & $\begin{array}{l}\text { They are composed of four layers: } \\
\text { outer, filter, cotton and inner layers. }\end{array}$ & $\begin{array}{l}80 \%-95 \% \\
\text { efficient of } \\
\text { particles down } \\
\text { to } 0.3 \mu \mathrm{m}\end{array}$ & $\begin{array}{l}\text { Virus, bacteria, } \\
\text { pollens, liquid-like } \\
\text { sprays against non- } \\
\text { oil particles }\end{array}$ & Yes & Reusable & 40 \\
\hline $\begin{array}{l}\text { Face } \\
\text { shield }\end{array}$ & Flimsier & $\begin{array}{l}\text { This mask is made of flimsier, which } \\
\text { cover the entire face from the } \\
\text { forehead to chin and is secure with a } \\
\text { headband cushioned. }\end{array}$ & $\begin{array}{l}\text { Effective with } \\
\text { perhaps surgical } \\
\text { or N95 masks } \\
\text { worn. }\end{array}$ & $\begin{array}{l}\text { Liquid like most } \\
\text { sprays. }\end{array}$ & No & Reusable & 40,46 \\
\hline SCBA & $\begin{array}{l}\text { A back-plate that holds the } \\
\text { cylinder and reduces the air from } \\
\text { high pressure ( } 200-300 \text { bar) to } \\
\text { medium pressure ( } 5-11 \text { bar) and, } \\
\text { in turn, supplies a face mask. }\end{array}$ & $\begin{array}{l}\text { Mostly worn by firefighters to ease } \\
\text { fresh breath when in contact with } \\
\text { hazardous environments. }\end{array}$ & $\begin{array}{l}99 \% \text { of knotter } \\
\text { than } 0.3 \mu \mathrm{m} .\end{array}$ & $\begin{array}{l}\text { Emergency } \\
\text { conditions, viruses, } \\
\text { bacteria, smoke } \\
\text { particles, and non- } \\
\text { oil particles. }\end{array}$ & Yes & Reusable & 40,46 \\
\hline
\end{tabular}


autoclaving or microwaving; and the application of ultraviolet radiation or dry heat. ${ }^{56}$ Unlike disposable medical masks and respirators, the material of cloth masks is unlikely to degrade from standard decontamination procedures. Hospitals, on the other hand, will be burdened with the additional task of washing and decontaminating worn masks. If healthcare personnel do decontamination on their own, they may not wash masks frequently enough, putting themselves at risk of infection. ${ }^{12}$

If you wear a none medical mask, do not touch it unnecessarily. Masks of any type are not comfortable and can cause users to touch their faces often to adjust the mask. This can be complicated, as that is specifically how the virus would enter your body.

Cloth masks should be washed after each use, or sooner if they appear soiled. Follow any particular instructions provided by the manufacturer. Use the warmest washer and dryer settings that are safe for the fabric. If you don't have access to a dryer or washer, you can wash a face mask in bleach and air dry it. To prepare the solution, add 4 tablespoons of bleach in $1 \mathrm{~L}$ of normal water, then saturate the mask in that solution for 4-5 min. After saturation, wash the mask thoroughly with normal water and let it air dry completely in presence of sunlight. ${ }^{57}$

In a nutshell, one must follow the following protocols to maintain the hygiene of the masks:

A. Store wet or dirty masks in a plastic bag: If your mask is filthy or wet from saliva, sweat, make-up, or different liquids or entities, keep it in an impenetrable plastic bag until you can clean it. To avoid mould growth, wash contaminated or wet masks as soon as possible. Damp masks are less useful than dry masks since they are difficult to breathe through. ${ }^{58,59}$

B. Masks that aren't damp or soiled should be stored in a clean paper bag: You can save your mask for later use by temporarily storing it. After touching a used mask, properly dispose of it and wash your hands. To keep it clean between uses, store it in a dry, breathable bag (such as a paper or mesh fabric bag). Keep the same side of your mask facing out while reusing it. If you need to remove your mask to drink or eat outside of the house, place it in a safe place, such as your pouch, handbag, or paper bag. After removing your mask, make sure to rinse or sanitize your hands. Replace the mask with the same side facing out after eating. After re-applying your mask, make sure to rinse or sterilise both hands once again. 58,59

C. Wash your mask: Wash your cotton mask whenever it gets soiled, or at least once a day. If you're using a disposable face mask, throw it away after one use. ${ }^{58}$

(i) Using a washing machine: Include your mask in your regular laundry. Use ordinary laundry detergent and the appropriate settings for the fabric, as directed on label. ${ }^{58}$

(ii) By hand: Rinse your mask with soap or laundry detergent and water. To get rid of any soap or detergent, wash it fully with clean water. $^{58}$

D. Dry your mask: Use a warm or hot drier to completely dry your mask. Allow your mask to dry completely in direct sunlight. If you can't dangle it in the sunshine, hang it or spread it out flat to dry. ${ }^{58}$

WHO is cooperating with research and development partners and the scientific community involved in fabric design and textile engineering to simplify a fine knowledge of the efficiency and utility of non-medical masks. WHO impulse countries that have emanated recommendations on the usage of both non-medical and medical masks by having people in community settings to propulsion research on this significant issue. Such research is urgent to look at if SARS-CoV-2 particles may be eradicated by non-medical masks of impoverished integrity worn through an individual with syndromes of COVID-19 if that individual is sneezing, speaking, or coughing. Research is also required on non-medical mask use by children and several medically difficult individuals and settings as above mentioned.
4.4. Categories of individuals who should wear medical masks against the expanse of COVID-19

Coronavirus disease (COVID-19) is an infectious disease caused by the SARS-CoV-2 virus, which was recently found. The mask is used in many ways depending on the type of person. ${ }^{60}$ These divisions are described properly below:

\subsection{Hospital}

\subsubsection{Monitoring area}

During interacting with victims, all medical crews such as nurses and the paramedical team would use disposable triple-layer surgical masks.

\subsubsection{Isolation department}

In the isolation cabins, all victims should be maintained that they must wear a disposable triple-layer surgical mask. Nursing and medical staff included in clinical caring in isolation faculties would need a triplelayer surgical mask, including extra Personal Protective Equipment (PPE). Nevertheless, if the staff is related to any aerosol-generating protocols like intubation, suction and nebulization then they must use the N95 respirator. Likewise, if the medical crew requisite to obtain clinical specimens from victims, then they must use $\mathrm{N} 95$ respirators. ${ }^{60}$

\subsubsection{Critical care faculty}

While nursing and medical staff are implicated in crucial care in the Intensive Care Unit (ICU) then they must utilize N95 Respirators.

\subsubsection{In laboratory room}

In laboratories, all staff are working and examining clinical samples related to pathogens like Influenza then they should use N95 Respirators.

\subsubsection{Mortuary}

Personnel involved in dealing with dead bodies of verified patients of seasonal influenza should utilize a triple-layer surgical mask, along with other infection measure procedures.

\subsubsection{Ambulance staff}

The motorist of the ambulance appointed for shifting patients with Influenza should utilize a triple-layer medical mask. The paramedics in the patient bedroom should borrow a triple-layer surgical mask and though the performance of any aerosol-generating procedures are contemplated (suction, oxygen administration by nasal catheter, intubation, nebulization, etc.) Likewise, in these situations, an N95 respirator should be worn at all times. ${ }^{60}$

\subsection{Health employees in community setting}

\subsubsection{Doctors}

Doctors treating Influenza-Like Illness (ILI) in general practice, as well as other health care workers working with them, should utilize a triple-layer surgical mask at the screening centre. ${ }^{60}$

\subsubsection{Healthcare workers}

Health workers involved in community surveillance contact tracing and health monitoring of cases at home or under home quarantine should use a triple-layer surgical mask. ${ }^{22}$

\subsubsection{Security personnel}

When operating in an infected/potentially infected location, such as an influenza ward in a screening centre or a hospital, security staff should wear a triple-layer surgical mask. ${ }^{22}$

The specifics of individuals who should use a medical mask or other respirators during certain activities are listed in Table 2. 


\subsection{Guidelines for using the mask for the general public}

Many countries recommend fabric masks or homemade masks for the common public to prevent the spread of pandemic disease.

\subsubsection{Public settings}

Masks should be worn in public locations, such as grocery shops, public meetings, at work, closed locations, along with schools, colleges, temples, mosques, churches, etc. In the above criteria, people should use a non-medical mask such as a cloth mask. ${ }^{60}$

\subsubsection{During transport}

Non-medical masks should be worn on public transit and in specific work scenarios that bring the person in close contact or potentially close contact with others, such as cashiers, social workers, and servers, and medical masks should be used only when necessary. ${ }^{60}$

\subsubsection{Senior citizens}

When people's age is above $\geq 60$, then they should use medical masks. However, $\mathrm{N} 95$ respirator masks can also be used for protection. ${ }^{60}$

\subsubsection{Other people}

People with underlying comorbidities, such as cardiovascular illness or chronic lung disease, diabetes mellitus, cancer, cerebrovascular disease, immunosuppression must use a medical mask. ${ }^{22,60}$

\subsubsection{Symptomatic public}

Persons with any syndromes suggestive of COVID-19 and close family contacts of such suspect/confirmed cases undergoing home care should also use a triple-layered medical mask. ${ }^{22,60}$

To prevent the coronavirus outbreak, the mask should be worn by $^{62,63}$ :

1. People who are 2 years of age and senior citizens.

2. Whenever you are in social background.

3. Each time when you are travelling on a bus, plane, train, or different kinds of public vehicle. Wear masks also in-vehicle hubs such as stations and airports.

4. At the time, when you are around folks who do not occupy with you, constituting inside your house or inside somebody else's residence.

5. Inside your house if somebody you stay with is sick with signs of COVID-19 or has tested positive for COVID-19.

Although, CDC acknowledges there are certain instances when wearing a face mask may not be conceivable always. In these instances, evaluate alternatives and adaptations.

The subsequent types of people can be exempted from the requirement to wear a face mask $^{62,63}$ :

1. A kid under the age of 2 years;

2. A person with a disability who cannot, or cannot safely, use a face mask for reasons related to their condition. ${ }^{62,63}$

3. Certain groups of people who may find it difficult to wear a mask: Relevant and consistent use of masks may be struggling for some children and communities of any age with specific disabilities, along with the people who have high sensitiveness to substances on their faces, trouble realizing why wearing a face mask is defensive (such as people with an intellectual disability), and those who have issues regulating their behavior in social situations. ${ }^{62,63}$

4. Those caring for youngsters and those with specific disabilities who may need assistance with wearing masks. In that scenario, they should seek advice from their healthcare providers concerning the person they're caring for who is wearing a mask. If they are unable to wear a mask, speak with their healthcare providers about other ways to reduce transmission risk and ensure proper mask fit and size. They should discard their mask before napping, sleeping, when they may
Table 2

Categories of individuals who should wear medical or other respiratory masks.

\begin{tabular}{|c|c|c|c|c|}
\hline Setting & $\begin{array}{l}\text { Categories } \\
\text { on } \\
\text { individuals }\end{array}$ & $\begin{array}{l}\text { Types of } \\
\text { masks }\end{array}$ & Activity & Reference \\
\hline \multirow[t]{3}{*}{ Screening } & $\begin{array}{l}\text { Health Care } \\
\text { Workers } \\
\text { (HCWs). }\end{array}$ & $\begin{array}{l}\text { Medical } \\
\text { mask. }\end{array}$ & $\begin{array}{l}\text { Preliminary } \\
\text { contact not } \\
\text { comprising } \\
\text { direct contact. }\end{array}$ & 46,61 \\
\hline & $\begin{array}{l}\text { Patients } \\
\text { with signs } \\
\text { suggestive } \\
\text { of COVID- } \\
19 .\end{array}$ & $\begin{array}{l}\text { Medical } \\
\text { mask. }\end{array}$ & Any & $34,46,61$ \\
\hline & $\begin{array}{l}\text { Patients } \\
\text { without } \\
\text { symptoms } \\
\text { suggestive } \\
\text { of COVID- } \\
19 .\end{array}$ & $\begin{array}{l}\text { If the } \\
\text { prevalence of } \\
\text { COVID-19 is } \\
\text { high, utilize a } \\
\text { medical } \\
\text { mask. But } \\
\text { when the } \\
\text { condition is } \\
\text { in control, } \\
\text { cloth face } \\
\text { coverings/ } \\
\text { masks may } \\
\text { be used. }\end{array}$ & Any & 46,61 \\
\hline \multirow[t]{2}{*}{ Patient room } & $\begin{array}{l}\text { Health Care } \\
\text { Workers } \\
\text { (HCWs) }\end{array}$ & $\begin{array}{l}\text { Medical } \\
\text { mask }\end{array}$ & $\begin{array}{l}\text { 1. Providing } \\
\text { direct care (no } \\
\text { aerosol- } \\
\text { generating } \\
\text { procedures) } \\
\text { 2. Direct care } \\
\text { (aerosol- } \\
\text { generating } \\
\text { methods are } \\
\text { repeatedly in } \\
\text { place) }\end{array}$ & 46,61 \\
\hline & Cleaners & $\begin{array}{l}\text { FFP2/N95 } \\
\text { respirators or } \\
\text { medical mask } \\
\text { if available }\end{array}$ & $\begin{array}{l}\text { When they are } \\
\text { entering the } \\
\text { patient's room } \\
\text { for cleaning or in } \\
\text { general when } \\
\text { they cleaning } \\
\text { contaminated } \\
\text { stuff. }\end{array}$ & 46,61 \\
\hline $\begin{array}{l}\text { Administrative } \\
\text { rooms }\end{array}$ & $\begin{array}{l}\text { All staff, } \\
\text { along with } \\
\text { HCWs. }\end{array}$ & $\begin{array}{l}\text { If they are } \\
\text { not in direct } \\
\text { contact with } \\
\text { patients } \\
\text { suffering } \\
\text { from COVID- } \\
19 \text { they can } \\
\text { Maintain } \\
\text { physical } \\
\text { distance (if } \\
\text { that is not } \\
\text { possible) } \\
\text { then they } \\
\text { should wear } \\
\text { an N95 or } \\
\text { cloth face } \\
\text { masks. }\end{array}$ & $\begin{array}{l}\text { Administrative } \\
\text { duties that do } \\
\text { not comprise } \\
\text { contact with } \\
\text { COVID-19 } \\
\text { patients. }\end{array}$ & 46,61 \\
\hline Laboratory & $\begin{array}{l}\text { Lab } \\
\text { technician }\end{array}$ & $\begin{array}{l}\text { N95/FFP2 } \\
\text { respirators }\end{array}$ & $\begin{array}{l}\text { Manipulation of } \\
\text { respiratory } \\
\text { specimens of } \\
\text { supposed } \\
\text { COVID-19 } \\
\text { patients. }\end{array}$ & $34,46,61$ \\
\hline \multirow[t]{2}{*}{$\begin{array}{l}\text { Waiting } \\
\text { compartment }\end{array}$} & $\begin{array}{l}\text { Patients } \\
\text { with signs } \\
\text { suggestive } \\
\text { of COVID- } \\
19\end{array}$ & $\begin{array}{l}\text { Medical } \\
\text { mask }\end{array}$ & Any & 46,61 \\
\hline & $\begin{array}{l}\text { Patients } \\
\text { without } \\
\text { signs }\end{array}$ & $\begin{array}{l}\text { Mask is not } \\
\text { required if } \\
\text { physical }\end{array}$ & Any & 46,61 \\
\hline
\end{tabular}


Table 2 (continued)

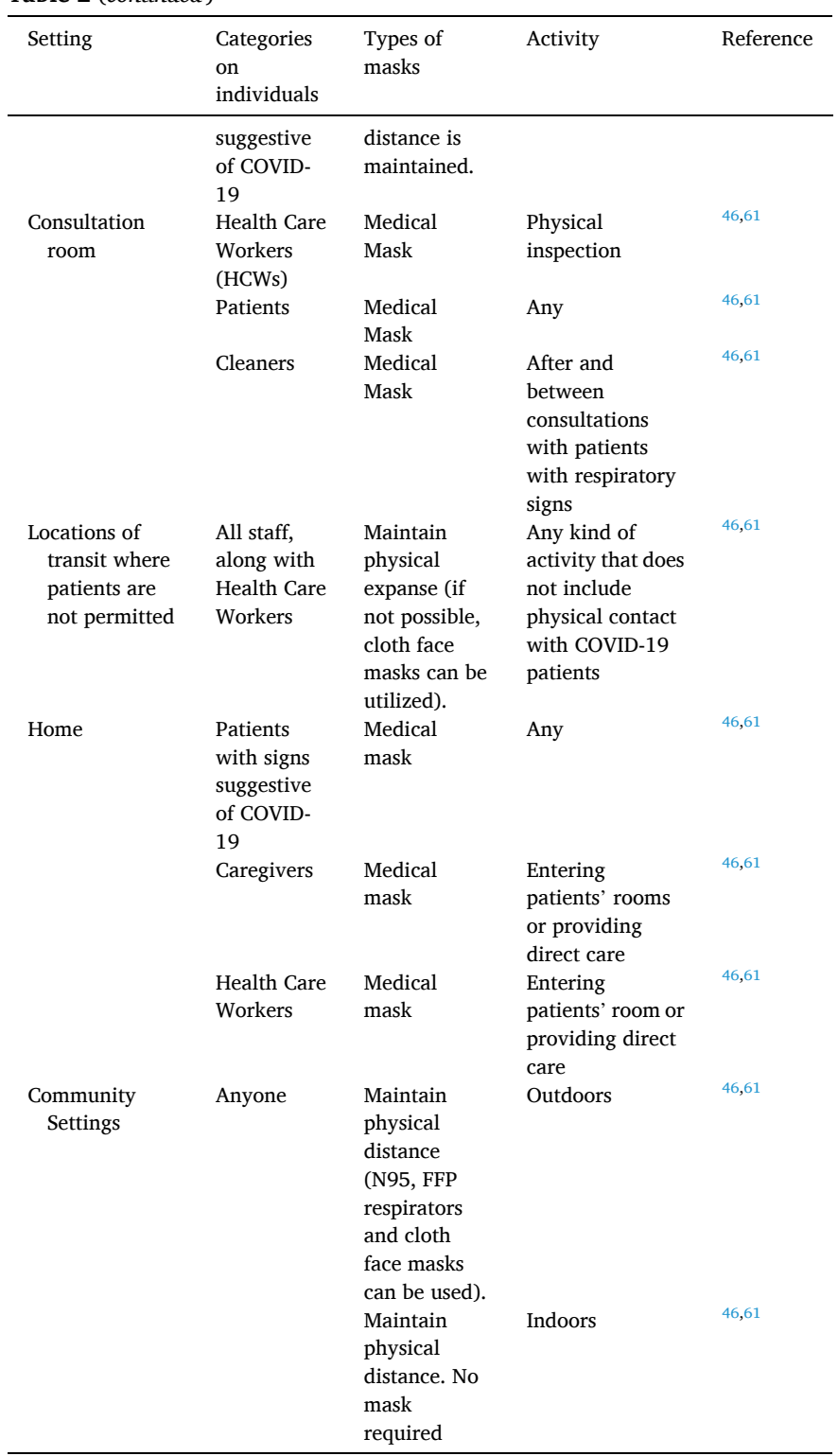

fall asleep (such as in a stroller or car seat), and in conditions when continuous maintenance is not feasible. ${ }^{62}$

But consider prioritizing wearing a mask at least in public locations and when around people who don't live in your home, especially when indoors. Masks may not be essential when you and the person you are looking after is away from each other, or with other people who live in the same home. Though some neighborhoods may have mask requirements while out in public and these requirements should always be obeyed. $^{62}$

People who are deaf or having difficulty in hearing, and those who will interact with people who have difficulty in the hearing should consider wearing a cloth mask with a clear panel. If you are unable to get a clear mask, consider utilizing written communication, closed featuring, or reducing background noise to make communication reasonable while wearing a mask that blocks lips.

People with specific underlying medical conditions like having any respiratory problem or asthma can also wear a mask, but they should first take advice from their doctor. ${ }^{62}$

If a person works in an area where masks could increase the risk of heat-related disease or cause safety issues (such as straps getting stuck in machinery), they should consult with a healthcare expert and occupational safety to determine whether the mask is appropriate or not. ${ }^{62}$

\subsection{Guidelines about utilizing masks in pandemic COVID-19}

Masks may be used for safety for healthy persons (when worn to defend themselves when in contact with an infected person) or for source supervision, according to the WHO's revised guidelines (worn through an infected person to obstruct onward transmission). ${ }^{64}$

The current protocols over face masks usage have deviated from the present guidelines provided by WHO. It was argued that there was insufficient evidence to suggest that healthy persons should wear face masks and that surgical face masks should only be worn by those who were sick or caring for patients. ${ }^{64}$

\subsection{Guidance on the use of masks in health care settings}

In the context of situations with acquainted or suspected society transmission or severe explosions of COVID-19, WHO provides the following guidance ${ }^{64,65}$ :

- Health employees, along with community health employees and caretakers, who are employed in clinical sectors should constantly wear a medical mask at the time of their periodic activities throughout the whole shift; apart from when drinking and eating or altering their mask to look after a patient who compels droplet precautions for other purposes. ${ }^{64,65}$

- According to the WHO statement, it is incredibly significant to obtain the constant usage of masks in probable massive transmission hazard areas along with triage, household physician, GP practices, emergency areas, outpatient divisions, cancer, transplant departments, long-period health crisis, COVID-19 determined departments and residential faculties. ${ }^{64}$

- Throughout the whole shift, at the time of utilizing medical masks, health employees should be assured that the medical mask is altered when damp, stained, or ruined; the medical mask is never contacted to adjust it or replaced from the face for any intention; the medical mask (as well as different personal protective equipment) is omitted and altered after taking care for any patient on droplet precautions for other pathogens. ${ }^{65}$

- Faculty members who do not work in the medical field are not required to wear a mask throughout their daily activities.

- Masks should never be shared among health professionals and should be suitably eliminated whenever discarded and never reused.

- A particulate respirator is as defensive as a US National Institute for Occupational Safety and Health-approved N99, N95, US FDA surgical N95, European Union standard FFP2 or FFP3, or equivalent, should be worn in environments for COVID-19 victims where AGPs are conducted. In these environments, the constant usage of masks by health professionals throughout their whole shift is highly recommended. ${ }^{64,65}$

- To be completely beneficial, the consecutive wearing of a face mask among health employees, throughout their exhaustive shift, should be executed along with maintaining constant hand hygiene and corporal distancing between health staff in disseminated and congested areas where mask usage can be unfeasible such as restaurants, clothing spaces, etc.

The probable risks and hazards should be gingerly taken into report when acquiring this strategy of targeted continuous usage of medical mask, which includes:

- Self-contamination owing to the manipulation of the face mask by filthy hands. $^{30,31}$

- Probable self-contamination can appear where medical masks are not altered when damp, contaminated or destroyed. 
- Conceivable advancement of facial skin injuries, stinging dermatitis, or deepening acne, when utilized for several hours.

- Masks perhaps uneasy to wear.

- Erroneous understanding of protection, heading to potentially minor allegiance to well-acknowledged preventative criteria certain as hand hygiene and corporal distancing.

- The hazard of droplet transmission and splashing to the eyes, whether mask-wearing is not integrated with eye safety.

- Inconvenience for or complication wearing masks by particular susceptible communities certain as those including mental health illnesses, the deaf, developmental disabilities, rough of hearing society, and children.

- A complication of wearing them in warm and moist atmospheres. ${ }^{66}$

\subsection{Guidance on the use of masks for the general public}

WHO approves that individuals with any symptoms suggestive of COVID-19 should follow these guidelines ${ }^{64,65}$ :

- Wearing a medical mask, self-sequester, and look for the medical recommendation as early as they begin to feel sick with possible symptoms of COVID-19, even if symptoms are mild. Symptoms include cough, fever, tiredness, loss of enthusiasm, muscle irritation, and shortness of breath. Other non-particular signs include bruise throat, diarrhoea, nasal congestion, headache, vomiting, nausea, losing of taste and odour foregoing the beginning of respiratory signs have further been reported. ${ }^{67,68}$

- Senior people and immunosuppressed sufferers may have anomalous symptoms such as exhaustion, lowered alertness, lessened mobility, diarrhoea, delirium, loss of hunger, and lack of fever. ${ }^{69-71}$ It is significant to report these initial symptoms for few people infected with COVID-19 may be very mild and indefinite.

- One must follow instructions on how to wear, take off, and dispose of face masks and maintain hand hygiene. ${ }^{22}$

- All additional conditions, particularly in respiratory hygiene, thorough hand washing, and maintaining a social distance of at least $1 \mathrm{~m}$ from other people, are required. ${ }^{72}$

In the circumstances of the COVID-19 pandemic, it is instructed that all individuals, nonetheless of whether they are utilizing face masks or not, should:

- Avoid mass gatherings.

- The physical distance of at least $1 \mathrm{~m}$ from another person should be followed, especially from the person with respiratory symptoms like gasping, coughing or sneezing.

- Practice hand hygiene repeatedly uses an alcohol-based hand sanitiser or soap and water.

- Use respiratory hygiene by covering the nose and mouth with a bent elbow or tissue paper when gasping or sneezing, after usage, discard the tissue instantly, and sanitize your hands with a sanitiser or soap and water.

- One should refrain from constant touching of eyes, nose and mouth.

\subsection{Guidance on the use of medical masks for the care of COVID-19 patients at home}

WHO delivers advice on how to look after patients with suspected COVID-19 at the household when looking after in a medical facility or other residential setting is not possible. Home care may be considered when isolation in non-traditional settings is unavailable or unsafe. Specific guidance for the use of medical mask at-home care is: ${ }^{73}$

- Always wear a mask and at least once a day changes the mask and use the fresh and dry mask.
- Individuals who cannot tolerate a medical mask must maintain respiratory hygiene and practice hand hygiene frequently.

- Always wear a mask when present in the same room as the infected person.

\subsection{Probable advantages of using masks ${ }^{22,73}$}

The potential benefits of the usage of masks by a healthy person:

- It helps in reducing the risk of exposure to infection from infected individuals before they develop any symptoms.

- Minimized probable stigmatization of people wearing masks to prohibit infecting others or of people looking after the COVID-19 patients in non-clinical environments.

- Make people realize that they can play a part in contributing to stopping the spread of the virus.

- Making people be responsible citizens by practising hand hygiene, not touching nose and mouth.

- It also provides social and economic privileges. Amidst the worldwide deficiency of PPE and surgical masks, urging the public to generate their cloth masks can emphasize personal business and public integration. Additionally, the output of non-medical masks may extend an origin of earnings for those who elect to develop masks among their societies.

- Fabric masks can further be a kind of cultural representation, motivating the public to an acknowledgement of safety regulations in general. The protected reuse of fabric masks will furthermore lessen waste, prices, and contribute to sustainability.

\subsection{Mask Management ${ }^{73}$}

For several types of masks, relevant usage and dumping are necessary to assure that they are beneficial and to ignore any upgrade in transmission.

WHO (World Health Organization) recommends the subsequent guidance on the appropriate usage of masks, derived from best procedures in health care settings ${ }^{22,73}$ :

- Before wearing the mask, always ensure hand hygiene.

- Avoid contacting the mask while wearing it.

- Wear the mask cautiously assuring it coats the nose or mouth, adjust to the nose, and wrap it securely to reduce any gaps between the face and the mask.

- Discard the mask using a reasonable technique.

- While removing the mask, do not touch the front part of the mask and remove it from the back.

- After disposal or a used mask is inadvertently touched, immediately clean hands with an alcohol-based sanitiser, or soap and water.

- Don't reuse again single-used masks.

- Replace the mask as early as it becomes damp with a new clean, dry mask.

- Abandon the single-use masks after each use and dispose of them carefully.

\section{Conclusion}

Covid-19 has created a huge impact on economic, educational, psychological, and people's livelihood worldwide. Regulating SARSCoV-2 transmission at the source by a face mask is a well-established strategy. Medical mask and N95 mask shortages have become major problems all over the world. Homemade cloth or fabric masks, however, were highly recommended by researchers as a way to reduce COVID-19 transmission. As per reports, there are no proven vaccines or specific treatments available which show cent percent efficacy to prevent this pandemic yet. Though the work has been going on vaccination by International research organizations and they developed several vaccines 
to date but nothing provides the hundred percent effectiveness against COVID-19. Until then, it is recommended that every individual should wear face masks in community places and maintain other protective measures. Everyone as a responsible citizen must follow the guidelines and instructions recommended by WHO and the Government to combat the pandemic situation.

The general public can use cloth masks especially cloth mask 1 as an alternative to medical and surgical masks in case they are not available. Till now, the three-layered cloth mask 1 provides the best filtering technique. Besides this people can also use the KN95 mask as an alternative to the N95 mask because it also provides similar effectiveness as N95 masks.

It is recommended for people to wear a mask whenever possible to prevent themselves from the coronavirus outbreak.

\section{Author contributions}

Conceptualization, J.S.; resources, S.D., A.D. and S.D.; writing—draft preparation, S.D., A.D., S.D., and S.S.; writing-review and editing, J.S. and S.S.; image preparation, P.C. and J.S.; visualization, J.S.; supervision, J.S.; All authors have read and agreed to the published version of the manuscript.

\section{Declaration of competing interest}

A conflict of interest occurs when an individual's objectivity is potentially compromised by a desire for financial gain, prominence, professional advancement or a successful outcome. CEGH Editors strive to ensure that what is published in the Journal is as balanced, objective and evidence-based as possible. Since it can be difficult to distinguish between an actual conflict of interest and a perceived conflict of interest, the Journal requires authors to disclose all and any potential conflicts of interest.

\section{Acknowledgements}

This study received no financial support from the government, commercial, or non-profit funding bodies.

\section{References}

1 WHO. WHO Director-General's Opening Remarks at the Media Briefing on COVID-19 11 March 2020.

2 Chan JFW, Kok KH, Zhu Z, et al. Genomic characterization of the 2019 novel humanpathogenic coronavirus isolated from a patient with atypical pneumonia after visiting Wuhan. Emerg Microb Infect. 2020;9(1):221-236. https://doi.org/10.1080/ 22221751.2020.1719902.

3 Cheng VCC, Wong SC, Chuang VWM, et al. The role of community-wide wearing of face mask for control of coronavirus disease 2019 (COVID-19) epidemic due to SARSCoV-2. J Infect. 2020;81(1):107-114. https://doi.org/10.1016/j.jinf.2020.04.024.

4 Cheng VCC, Wong SC, To KKW, Ho PL, Yuen KY. Preparedness and proactive infection control measures against the emerging novel coronavirus in China. $J$ Hosp Infect. 2020;104(3):254-255. https://doi.org/10.1016/j.jhin.2020.01.010.

5 Cheng VCC, Wong SC, Chen JHK, et al. Escalating infection control response to the rapidly evolving epidemiology of the coronavirus disease 2019 (COVID-19) due to SARS-CoV-2 in Hong Kong. Infect Control Hosp Epidemiol. 2020;41(5):493-498. https://doi.org/10.1017/ice.2020.58.

6 Olliaro P, Torreele E, Vaillant M. COVID-19 vaccine efficacy and effectiveness-the elephant (not) in the room. The Lancet Microbe. 2021. https://doi.org/10.1016/ s2666-5247(21)00069-0, 0(0).

7 Bar-Zeev N, Inglesby T. COVID-19 vaccines: early success and remaining challenges. Lancet. 2020;396(10255):868-869. https://doi.org/10.1016/S0140-6736(20)31867 5.

8 Kaur SP, Gupta V. COVID-19 Vaccine: a comprehensive status report. Virus Res. 2020; 288:198114. https://doi.org/10.1016/j.virusres.2020.198114.

9 Howard J, Huang A, Li Z, et al. Face Masks against COVID-19: An Evidence Review. Published online April 2020. doi:10.20944/preprints202004.0203.v1.

10 Abd-Elsayed A, Karri J. Utility of substandard face mask options for health care workers during the COVID-19 pandemic. Anesth Analg. Published online 2020:4-6. doi:10.1213/ANE.0000000000004841.

11 Lisa Allison A, Ambrose-Dempster E, Domenech Aparsi T, Bawn M, Casas M. Article title: the impact and effectiveness of the general public wearing masks to reduce the spread of pandemics in the UK: a multidisciplinary comparison of single-use masks versus reusable face masks. UCL Open Environ Prepr. Published online October 2020. doi:10.14324/111.444/000031.v2.

12 MacIntyre CR, Chughtai AA, Rahman B, et al. The efficacy of medical masks and respirators against respiratory infection in healthcare workers. Influenza Other Respi Viruses. 2017;11(6):511-517. https://doi.org/10.1111/irv.12474.

13 Davies A, Thompson KA, Giri K, Kafatos G, Walker J, Bennett A. Testing the efficacy of homemade masks: would they protect in an influenza pandemic? Disaster Med Public Health Prep. 2013;7(4):413-418. https://doi.org/10.1017/dmp.2013.43.

14 Ong SWX, Tan YK, Chia PY, et al. Air, surface environmental, and personal protective equipment contamination by severe acute respiratory syndrome coronavirus 2 (SARS-CoV-2) from a symptomatic patient. JAMA, J Am Med Assoc. 2020;323(16): 1610-1612. https://doi.org/10.1001/jama.2020.3227.

15 Liu J, Liao X, Qian S, et al. Community transmission of severe acute respiratory syndrome Coronavirus 2, Shenzhen, China, 2020. Emerg Infect Dis. 2020;26(6): 1320-1323. https://doi.org/10.3201/eid2606.200239.

16 Guo ZD, Wang ZY, Zhang SF, et al. Aerosol and surface distribution of severe acute respiratory syndrome coronavirus 2 in hospital wards, wuhan, China, 2020. Emerg Infect Dis. 2020;26(7):1586-1591. https://doi.org/10.3201/eid2607.200885.

17 Van Doremalen N, Bushmaker T, Morris DH, et al. Aerosol and surface stability of SARS-CoV-2 as compared with SARS-CoV-1. N Engl J Med. 2020;382(16):1564-1567. https://doi.org/10.1056/NEJMc2004973.

18 Wölfel R, Corman VM, Guggemos W, et al. Virological assessment of hospitalized patients with COVID-2019. Nature. 2020;581(7809):465-469. https://doi.org/ 10.1038/s41586-020-2196-X.

19 Yu P, Zhu J, Zhang Z, Han Y. A familial cluster of infection associated with the 2019 novel coronavirus indicating possible person-to-person transmission during the incubation period. J Infect Dis. 2020;221(11):1757-1761. https://doi.org/10.1093/ infdis/jiaa077.

20 Lauer SA, Grantz KH, Bi Q, et al. The incubation period of coronavirus disease 2019 (CoVID-19) from publicly reported confirmed cases: estimation and application. Ann Intern Med. 2020;172(9):577-582. https://doi.org/10.7326/M20-0504.

21 Kimball A, Hatfield KM, Arons M, et al. Asymptomatic and presymptomatic SARSCoV-2 infections in residents of a long-term care skilled nursing facility - king county, Washington, March 2020. MMWR Morb Mortal Wkly Rep. 2020;69(13): 377-381. https://doi.org/10.15585/mmwr.mm6913e1.

22 Advice on the Use of Masks in the Community, during Home Care and in Healthcare Settings in the Context of the Novel Coronavirus (COVID-19) Outbreak.

23 Migliori GB, Nardell E, Yedilbayev A, et al. Reducing tuberculosis transmission: a consensus document from the world health organization regional office for europe. Eur Respir J. 2019;53(6). https://doi.org/10.1183/13993003.00391-2019.

24 Dharmadhikari AS, Mphahlele M, Stoltz A, et al. Surgical face masks worn by patients with multidrug-resistant tuberculosis: impact on infectivity of air on a hospital ward. Am J Respir Crit Care Med. 2012;185(10):1104-1109. https://doi.org/ 10.1164/rccm. 201107-11900C.

25 Long Y, Hu T, Liu L, et al. Effectiveness of N95 respirators versus surgical masks against influenza: a systematic review and meta-analysis. J Evid Base Med. 2020;13 (2):93-101. https://doi.org/10.1111/jebm.12381.

26 Bae S, Kim MC, Kim JY, et al. Retraction: effectiveness of surgical and cotton masks in blocking SARS-CoV-2: a controlled comparison in 4 patients (annals of internal medicine (2020)). Ann Intern Med. 2020;173(1):W22-W23. https://doi.org/ 10.7326/M20-1342.

27 Jiang S-C, Zhang Z-W, Fu Y-F, et al. More Patient Deaths: A Correlation Analysis. vol. 12. 2019.

28 van der Sande M, Teunis P, Sabel R. Professional and Home-Made Face Masks Reduce Exposure to Respiratory Infections Among the General PopulationPai M, ed. PloS One. 2008; vol. 3(7), e2618. https://doi.org/10.1371/journal.pone.0002618.

29 Papineni RS, Rosenthal FS. The size distribution of droplets in the exhaled breath of healthy human subjects. J Aerosol Med Depos Clear Eff Lung. 1997;10(2):105-116. https://doi.org/10.1089/jam.1997.10.105.

30 How to Protect Yourself \& Others | CDC.

31 Wang X, Pan Z, Cheng Z. Association between 2019-nCoV transmission and N95 respirator use. J Hosp Infect. 2020;105(1):104-105. https://doi.org/10.1016/j. jhin.2020.02.021.

32 Setti L, Passarini F, De Gennaro G, et al. Airborne transmission route of covid-19: why 2 meters 6 feet of inter-personal distance could not be enough. Int $J$ Environ Res Publ Health. 2020;17(8):2932. https://doi.org/10.3390/ijerph17082932.

33 Theresa Tam Offers New Advice: Wear a Non-medical Face Mask when Shopping or Using Public Transit - the Globe and Mail.

34 Yang P, Seale H, Raina MacIntyre C, et al. Mask-wearing and respiratory infection in healthcare workers in Beijing, China. Braz J Infect Dis. 2011;15(2):102-108. https:// doi.org/10.1016/s1413-8670(11)70153-2.

35 Jain M, Kim ST, Xu C, Li H, Rose G. Efficacy and Use of Cloth Masks: A Scoping Review. doi:10.7759/cureus.10423.

36 Pang X, Zhu Z, Xu F, et al. Evaluation of control measures implemented in the severe acute respiratory syndrome outbreak in Beijing, 2003. J Am Med Assoc. 2003;290 (24):3215-3221. https://doi.org/10.1001/jama.290.24.3215.

37 Shakya KM, Noyes A, Kallin R, Peltier RE. Evaluating the efficacy of cloth facemasks in reducing particulate matter exposure. $J$ Expo Sci Environ Epidemiol. 2017;27(3): 352-357. https://doi.org/10.1038/jes.2016.42.

38 Ma QX, Shan H, Zhang HL, Li GM, Yang RM, Chen JM. Potential utilities of maskwearing and instant hand hygiene for fighting SARS-CoV-2. J Med Virol. 2020;92(9): 1567-1571. https://doi.org/10.1002/jmv.25805.

39 Investigation and Initial Clinical Management of Possible Human Cases of Avian Influenza Viruses that Have Been Associated with Severe Human Disease. 2020.

40 Tcharkhtchi A, Abbasnezhad N, Zarbini Seydani M, Zirak N, Farzaneh S, Shirinbayan M. An overview of filtration efficiency through the masks: mechanisms 
of the aerosols penetration. Bioact Mater. 2021;6(1):106-122. https://doi.org/ 10.1016/j.bioactmat.2020.08.002.

41 J G, M C, C M, B C Evaluating the Protection Afforded by Surgical Masks against Influenza Bioaerosols : Gross Protection of Surgical Masks Compared to Filtering Facepiece Respirators. Published online January 2008.

42 Bałazy A, Toivola M, Adhikari A, Sivasubramani SK, Reponen T, Grinshpun SA. Do N95 respirators provide 95\% protection level against airborne viruses, and how adequate are surgical masks? Am J Infect Contr. 2006;34(2):51-57. https://doi.org/ 10.1016/j.ajic.2005.08.018.

43 Marambio-Jones C, Hoek EMV. A review of the antibacterial effects of silver nanomaterials and potential implications for human health and the environment. J Nanoparticle Res. 2010;12(5):1531-1551. https://doi.org/10.1007/s11051-0109900-y.

44 Lindsley WG, Noti JD, Blachere FM, Szalajda JV, Beezhold DH. Efficacy of face shields against cough aerosol droplets from a cough simulator. J Occup Environ Hyg. 2014;11(8):509-518. https://doi.org/10.1080/15459624.2013.877591.

45 Makison Booth C, Clayton M, Crook B, Gawn JM. Effectiveness of surgical masks against influenza bioaerosols. J Hosp Infect. 2013;84(1):22-26. https://doi.org/ 10.1016/j.jhin.2013.02.007.

46 MacIntyre CR, Chughtai AA. Facemasks for the prevention of infection in healthcare and community settings. BMJ. 2015;350. https://doi.org/10.1136/bmj.h694.

47 Patel RB, Skaria SD, Mansour MM, Smaldone GC. Respiratory source control using a surgical mask: an in vitro study. J Occup Environ Hyg. 2016;13(7):569-576. https:// doi.org/10.1080/15459624.2015.1043050.

48 Leung NHL, Chu DKW, Shiu EYC, et al. Respiratory virus shedding in exhaled breath and efficacy of face masks. Nat Med. 2020;26(5):676-680. https://doi.org/10.1038/ s41591-020-0843-2.

49 Johnson DF, Druce JD, Birch C, Grayson ML. A quantitative assessment of the efficacy of surgical and N95 masks to filter influenza virus in patients with acute influenza infection. Clin Infect Dis. 2009;49(2):275-277. https://doi.org/10.1086/ 600041.

50 Milton DK, Fabian MP, Cowling BJ, Grantham ML, McDevitt JJ. Influenza virus aerosols in human exhaled breath: particle size, culturability, and effect of surgical masks. PLoS Pathog. 2013;9(3):1003205. https://doi.org/10.1371/journal. ppat.1003205.

51 Seto WH, Tsang D, Yung RWH, et al. Effectiveness of precautions against droplets and contact in prevention of nosocomial transmission of severe acute respiratory syndrome (SARS). Lancet. 2003;361(9368):1519-1520. https://doi.org/10.1016/ S0140-6736(03)13168-6.

52 Radonovich LJ, Simberkoff MS, Bessesen MT, et al. N95 respirators vs medical masks for preventing influenza among health care personnel: a randomized clinical trial. JAMA, J Am Med Assoc. 2019;322(9):824-833. https://doi.org/10.1001/ jama.2019.11645.

53 Offeddu V, Yung CF, Low MSF, Tam CC. Effectiveness of masks and respirators against respiratory infections in healthcare workers: a systematic review and metaanalysis. Clin Infect Dis. 2017;65(11):1934-1942. https://doi.org/10.1093/cid/ cix681.

54 Eikenberry SE, Mancuso M, Iboi E, et al. To mask or not to mask: modeling the potential for face mask use by the general public to curtail the COVID-19 pandemic. Infect Dis Model. 2020;5:293-308. https://doi.org/10.1016/j.idm.2020.04.001.
55 Liao L, Xiao W, Zhao M, et al. Can N95 respirators Be reused after disinfection? How many times? ACS Nano. 2020;14(5):6348-6356. https://doi.org/10.1021/ acsnano.0c03597.

56 THE NATIONAL ACADEMIES PRESS Reusability of Facemasks during an Influenza Pandemic: Facing the Flu. 2006. https://doi.org/10.17226/11637. Published online 2006.

57 A Guide to Using Nonmedical Masks - UTHealth News - UTHealth..

58 How to Wash a Cloth Face Covering / CDC..

59 Coronavirus Disease (COVID-19): Masks.

60 Assadi M, Gholamrezanezhad A, Jokar N, et al. Key elements of preparedness for pandemic coronavirus disease 2019 (COVID-19) in nuclear medicine units. Eur J Nucl Med Mol Imag. 2020;47(8):1779-1786. https://doi.org/10.1007/s00259-020-047804.

61 Cook TM. Personal protective equipment during the coronavirus disease (COVID) 2019 pandemic - a narrative review. Anaesthesia. 2020;75(7):920-927. https://doi. org/10.1111/anae.15071.

62 COVID-19: Considerations for Wearing Masks | CDC.

63 Your Guide to Masks | CDC.

64 WHO Infection Prevention and Control of Epidemic-And Pandemic Prone Acute Respiratory Infections in Health Care. WHO; 2015. Published online.

65 Infection Prevention and Control during Health Care when Novel Coronavirus (nCoV) Infection Is Suspected.

66 Ł Matusiak, Szepietowska M, Krajewski PK, Białynicki-Birula R, Szepietowski JC. The use of face masks during the COVID-19 pandemic in Poland: a survey study of 2315 young adults. Dermatol Ther; 2020. https://doi.org/10.1111/dth.13909. Published online.

67 Giacomelli A, Pezzati L, Conti F, et al. Self-reported olfactory and taste disorders in patients with severe acute respiratory coronavirus 2 infection: a cross-sectional study. Clin Infect Dis. 2020;71(15):889-890. https://doi.org/10.1093/cid/ciaa330.

68 Tong JY, Wong A, Zhu D, Fastenberg JH, Tham T. The prevalence of olfactory and gustatory dysfunction in COVID-19 patients: a systematic review and meta-analysis. Otolaryngol Head Neck Surg. 2020;163(1):3-11. https://doi.org/10.1177/ 0194599820926473.

69 Arons MM, Hatfield KM, Reddy SC, et al. Presymptomatic SARS-CoV-2 infections and transmission in a skilled nursing facility. $N$ Engl J Med. 2020;382(22):2081-2090. https://doi.org/10.1056/NEJMoa2008457.

70 Tay HS, Harwood R. Atypical presentation of COVID-19 in a frail older person. Age Ageing. 2020;49(4):523-524. https://doi.org/10.1093/ageing/afaa068.

71 McMichael TM, Currie DW, Clark S, et al. Epidemiology of covid-19 in a long-term care facility in King County, Washington. N Engl J Med. 2020;382(21):2008-2011. https://doi.org/10.1056/NEJMoa2005412.

72 Chu DK, Akl EA, Duda S, Solo K, Yaacoub S, Schünemann HJ. Physical distancing, face masks, and eye protection to prevent person-to-person transmission of SARSCoV-2 and COVID-19: a systematic review and meta-analysis. www.thelancet.com; 2020, 395.

73 World Health Organization. Home Care for Patients with Suspected Novel Coronavirus (COVID-19) Infection Presenting with Mild Symptoms, and Management of Their Contacts: Interim Guidance, 04 February 2020. World Heal. World Health Organization; 2020, 2020. 